\title{
Do Board Secretaries Influence Management Earnings Forecasts?
}

\author{
Lu Xing ${ }^{1}$ Tinghua Duan ${ }^{1,2} \cdot$ Wenxuan Hou ${ }^{1,3}$
}

Received: 22 August 2016/ Accepted: 19 February 2017/Published online: 3 March 2017

(C) The Author(s) 2017. This article is published with open access at Springerlink.com

\begin{abstract}
The role of board secretaries is a unique institutional feature in China. Individuals in this senior executive role are responsible for coordinating information disclosure. We study the impact of board secretaries on management earnings forecasts and find that their legal expertise, accounting expertise and foreign experience help improve management earnings forecast quality. The quality of forecasts, as indicated by their occurrence, frequency, precision and accuracy, is also positively associated with the role duality (e.g. board director, CFO or other senior executive role) and equity holdings of board secretaries and negatively associated with their political connection. The quality of forecasts is found to increase the compensation of board secretaries. Finally, we show that the equity holding of board secretaries reduces litigation risks and increases corporate philanthropic giving.
\end{abstract}

Keywords Board secretary $\cdot$ Management earnings forecasts - China - Top management team - Litigation risk

JEL classification $\mathrm{G} 30 \cdot \mathrm{M} 12 \cdot \mathrm{M} 41$

Electronic supplementary material The online version of this article (doi:10.1007/s10551-017-3478-6) contains supplementary material, which is available to authorized users.

Wenxuan Hou

wenxuan.hou@ed.ac.uk

1 University of Edinburgh Business School, University of Edinburgh, 29 Buccleuch Place, Edinburgh EH8 9JS, UK

2 Stern School of Business, New York University, New York, NY 10012, USA

3 School of Government Audit, Nanjing Audit University, 86 West Yushan Road, Nanjing, China

\section{Introduction}

Managers often release earnings forecasts prior to the actual earnings announcement to show their ability to anticipate economic environment changes and adjust production plans (Trueman 1986). Various characteristics of a top management team (TMT) influence the style of management earnings forecasts (Bamber et al. 2010). The literature largely examines the roles of Chief Financial Officer (Geiger and North 2006; Jiang et al. 2010), Chief Counsel $^{1}$ (Bird et al. 2015; Hopkins et al. 2014; Kwak et al. 2012), Chief Risk Officer (Adabo et al. 2005), Chief Knowledge Officer (Earl and Scott 1999) and Chief Marketing Officer (Nath and Mahajan 2008). ${ }^{2}$ The Company Law of the People's Republic of China requires listed companies to establish a board secretary post to coordinate information disclosure and board meetings from the beginning of 2006. The role of board secretaries has not been studied in the literature, and we intend to shed light on this area by examining how they influence management earnings forecasts.

Although board secretaries in China and company secretaries in other countries share responsibilities for coordinating boards and executives, managing internal information flow and ensuring regulatory compliance, ${ }^{3}$ board secretaries are also responsible for information disclosure and organisations' relationships with their investors. Since managers' personal characteristics are found to

\footnotetext{
1 The Chief Counsel is the head of the legal department, and is also known as General Counsel (GC) or Chief Legal Officer (CLO).

2 Table 1 summarises these studies.

${ }^{3}$ McNulty and Stewart (2015) summarise that company secretaries are responsible for statutory returns and regulatory compliance, supporting board chairs and influencing board processes and outcomes.
} 
Table 1 Summary of studies of non-CEO top managers

\begin{tabular}{|c|c|c|c|}
\hline Authors & Types of top manager & Sample & Main findings \\
\hline $\begin{array}{l}\text { Geiger and } \\
\text { North } \\
(2006)\end{array}$ & Chief Financial Officer & $\begin{array}{l}712 \text { US companies from } \\
1994 \text { to } 2000\end{array}$ & $\begin{array}{l}\text { The newly appointment CFO in this study is associated with } \\
\text { lower discretionary accruals, especially if it is an external } \\
\text { appointment }\end{array}$ \\
\hline $\begin{array}{l}\text { Jiang et al. } \\
\text { (2010) }\end{array}$ & Chief Financial Officer & $\begin{array}{l}\text { S\&P } 1500 \text { firms in the } \\
\text { US from } 1993 \text { to } 2006\end{array}$ & $\begin{array}{l}\text { The magnitude of accruals and the likelihood of beating analysts' } \\
\text { forecasts are more sensitive to CFO equity incentives than to } \\
\text { those of the CEO }\end{array}$ \\
\hline $\begin{array}{l}\text { Barua et al. } \\
\text { (2010) }\end{array}$ & Chief Financial Officer & $\begin{array}{l}2938 \text { US firms from } \\
2004 \text { to } 2005\end{array}$ & $\begin{array}{l}\text { Female CFOs have lower performance-matched absolute } \\
\text { discretionary accruals and lower absolute accrual estimation } \\
\text { errors }\end{array}$ \\
\hline $\begin{array}{l}\text { Beck and } \\
\text { Mauldin } \\
(2014)\end{array}$ & Chief Financial Officer & $\begin{array}{l}\text { US firms from } 2006 \text { to } \\
2009\end{array}$ & $\begin{array}{l}\text { During the recession, the presence of more powerful CFOs is } \\
\text { associated with larger audit fee reductions, and the presence of a } \\
\text { more powerful audit committee is associated with lower audit } \\
\text { fee reductions }\end{array}$ \\
\hline $\begin{array}{l}\text { Bird et al. } \\
\quad(2008)\end{array}$ & $\begin{array}{l}\text { Chief Counsel (also known as } \\
\text { Chief Legal Officer or General } \\
\text { Counsel) }\end{array}$ & $\begin{array}{l}\text { S\&P } 500 \text { firms in the } \\
\text { US from } 2000 \text { to } 2010\end{array}$ & $\begin{array}{l}\text { Chief Counsel tend to have lower compensation when the } \\
\text { preceding year's Tobin's Q is high and firms have more insiders } \\
\text { on their boards. In addition, lawsuits are positively correlated } \\
\text { with CEO and CFO turnover but not CLO turnover }\end{array}$ \\
\hline $\begin{array}{l}\text { Hopkins } \\
\text { et al. } \\
\text { (2014) }\end{array}$ & Chief Counsel & $\begin{array}{l}2133 \text { US firms in } \\
\text { ExecuComp from } \\
2001 \text { to } 2011\end{array}$ & $\begin{array}{l}\text { Chief Counsels with high compensation are associated with lower } \\
\text { quality financial reports and more aggressive accounting } \\
\text { practices, including management of the litigation reserve }\end{array}$ \\
\hline $\begin{array}{l}\text { Kwak et al. } \\
\text { (2012) }\end{array}$ & Chief Counsel & $\begin{array}{l}\text { S\&P } 1500 \text { US firms } \\
\text { from } 1997 \text { to } 2009\end{array}$ & $\begin{array}{l}\text { Firms with a Chief Counsel in top management are more likely to } \\
\text { issue forecasts, particularly bad news forecasts, than other firms }\end{array}$ \\
\hline $\begin{array}{l}\text { Earl and } \\
\text { Scott } \\
(1999)\end{array}$ & Chief Knowledge Officer & Theoretical Paper & $\begin{array}{l}\text { Companies are creating the } \mathrm{CKO} \text { position to initiate, drive and } \\
\text { coordinate knowledge management programs }\end{array}$ \\
\hline $\begin{array}{l}\text { Nath and } \\
\text { Mahajan } \\
\text { (2008) }\end{array}$ & Chief Marketing Officer & $\begin{array}{l}167 \text { US firms from } 2000 \\
\text { to } 2004\end{array}$ & $\begin{array}{l}\text { The presence of a CMO is associated with innovation, } \\
\text { differentiation, branding strategy, diversification, TMT } \\
\text { functional experience in marketing and external CEOs }\end{array}$ \\
\hline $\begin{array}{l}\text { Aabo et al. } \\
(2005)\end{array}$ & Chief Risk Officer & $\begin{array}{l}\text { Hydro One, a Canadian } \\
\text { electric utility } \\
\text { company }\end{array}$ & $\begin{array}{l}\text { The process of implementation a CRO has helped make risk } \\
\text { awareness an important part of the corporate culture }\end{array}$ \\
\hline
\end{tabular}

influence management earnings forecasts (Bamber et al. 2010), we expect that professional expertise could influence the professional ability of board secretaries in fulfilling their earnings forecasts duties. Board secretaries with legal expertise are better aware of litigation risks and tend to make fair forecasts to reduce information asymmetry (Kwak et al. 2012). Board secretaries with an accounting background have good knowledge of firms' financial situation and can make more accurate forecasts. Board secretaries with international experience tend to possess knowledge about more advanced legal institutions and better corporate governance (Duan and Hou 2016; Giannetti et al. 2013) and are therefore expected to improve the quality of management earnings forecasts.

Political connection is another important manager characteristic in China. Since politically connected managers are likely to establish management entrenchment in firms, they are less likely to be replaced, decreasing their incentive to improve firm performance (Cao et al. 2011; You and Du 2012). In addition, politically connected managers in state-owned enterprises (SOEs) may pursue social objectives rather than the maximisation of shareholders' wealth (Fan et al. 2007). Politically connected board secretaries tend to former bureaucrats who lack business knowledge and experience. We therefore expect that politically connected board secretaries, measured as those with Communist Party membership, are likely to issue low-quality forecasts.

Role duality for board secretaries is common. Many board secretaries also serve as a board member, CFO or other senior executive. Role duality may lead to information advantage, more power (Finkelstein 1992) and stronger leadership (Finkelstein and D'aveni 1994). We expect that board secretaries holding dual roles are able to access more information and resources, leading to high-quality management earnings forecasts.

Finally, managerial ownership can align the interests of managers and shareholders and mitigate agency problems (Jensen and Meckling 1976; Datta et al. 2005). For example, Nagar et al. (2003) show that alignment of CEO 
and shareholders' interests increases the frequency of management earnings forecasts. We therefore predict that board secretaries with more equity holdings are more willing to serve the interests of shareholders and issue high-quality management forecasts.

To test our four predictions, we collect the characteristics of board secretaries between 2001 and 2011 from their biographies. We use this sample to examine the impact of board secretaries on the occurrence, frequency, precision, accuracy and optimism of management earnings forecasts. The results support our predictions: the quality of management earnings forecasts are positively associated with the expertise, role duality and equity holdings of board secretaries, but negatively associated with their political connection. We further find that board secretaries with accounting expertise, dual senior roles and equity holding are more likely to issue bad news and downward guidance forecasts, which help reduce legal and reputational risks. We also investigate the influence of management earnings forecasts on corporate decisions regarding board secretaries' pay and turnover, finding that board secretaries who issue high-quality earnings forecasts tend to receive higher compensation and have more stable job retention. Finally, we perform additional analyses to examine the board secretaries' impact on corporate policy and find that equity holding of board secretaries reduces firms' litigation risk and increases corporate social responsibility. Overall, the results suggest the important role of board secretaries in management earnings forecasts.

Our study contributes to the literature in three ways. First, to the best of our knowledge, this is the first study on board secretaries, opening a new research avenue for TMT studies. It also complements the existing literature on the roles of Chief Financial Officer (Geiger and North 2006; Jiang et al. 2010), Chief Counsel (Bird et al. 2015; Hopkins et al. 2014; Kwak et al. 2012), Chief Risk Officer (Adabo et al. 2005), Chief Knowledge Officer (Earl and Scott 1999) and Chief Marketing Officer (Nath and Mahajan 2008).

Second, this paper adds to the management forecast literature by documenting a new managerial determinant. The existing literature reports the impact of the demographic characteristics of top managers, including CEOs, CFOs and Chief Counsel, on firms' forecasting decisions (Bamber et al. 2010; Brochet et al. 2011; Baik et al. 2011; Kwak et al. 2012; Cassell et al. 2013). We provide original evidence that the quality of management earnings forecasts is related to professional expertise, political connections, role duality and equity holdings of board secretaries.

Third, this paper contributes to studies of managerial effects on business ethics (Chen et al. 2016; Lee 2015; Rogers and Stocken 2005; Slater and Dixon-Fowler 2009). Since high-quality information disclosure is a fundamental element of ethical communication (Holley 1998; Ruppel and Harrington 2000), management earnings forecasts play a key role in investor protection. Ethical managers should provide high-quality forecast information to stakeholders. In addition, we show the impact of board secretaries on litigation risks and corporate social responsibility.

This study has important policy implications for regulators and policy makers in China who aim to establish an effective governance mechanism within the particular context of China. Our results suggest that certain requirements regarding the expertise and ownership of board secretaries will be helpful in enhancing management forecasts. In addition, firms can consider appointing a board member or senior executive as board secretary. Taking on a second role can actually help increase forecast quality and will not lead to a busyness problem.

The remainder of the paper is organised as follows. Section 2 introduces the institutional background. Section 3 reviews the related literature and develops the hypotheses. Section 4 describes the sample and the research design. Section 5 presents the empirical results, Sect. 6 performs additional analyses, and Sect. 7 concludes.

\section{Institutional Background}

The top management team (TMT) is a group of individuals who manage the daily operations of companies at the highest level. Top management teams typically include the Chief Executive Officer (CEO), Chief Financial Officer (CFO), Chief Technology Officer (CTO), Chief Operations Officer (COO), Chief Marketing Officer (CMO), Chief Counsels, and Chief Risk Officer (CRO).

A unique corporate governance mechanism in China, the board secretary is a post that is required by law to be present in top management teams. Board secretaries play a key role by being in charge of corporate information disclosure, as specified in the Guidance for the Articles of Listed Company (1997), Company Law of the People's Republic of China (2005). The Rules Governing the Listing of Stocks on Shanghai Stock Exchange (2008) and the Rules Governing the Listing of Stocks on Shenzhen Stock Exchange (2008) further strengthen board secretaries' information disclosure duties by stating that "a listed company must establish an information disclosure department and put the board secretary to manage this department"; "the board secretary is responsible for disclosing material information to the public, coordinating information disclosure matters, establishing standardised information disclosure systems and urging other managers to observe relevant disclosure regulations"; and "the board secretary is responsible for disclosing corporate 
information in a timely manner, ensuring confidentiality with regard to information disclosures and reporting to the stock exchange whenever any non-published material information is leaked." 4

Board secretaries have other important obligations. For example, (1) board secretaries are responsible for ensuring corporate decisions comply with laws and regulations by providing professional legal advice to management; (2) they educate other managers about the latest rules and regulations on information disclosure; (3) they act as a liaison between firms and different regulatory agencies, such as the China Securities Regulatory Commission (CRSC), the Shanghai and Shenzhen stock exchanges and local securities authorities; and (4) they answer the consulting calls of investors, communicate with media reporters and assist securities analysts in their investigations. Overall, board secretaries perform multiple duties in management and operations to improve information disclosure and corporate governance.

The concept of Chinese board secretaries is originated from company secretaries in Western countries. Although individuals in both roles serve as senior executives in charge of issues such as the provision of legal assistance, safekeeping of business documents and maintaining contact with investors, Chinese board secretaries differ greatly from company secretaries in certain aspects. Since the Model Business Corporation Act of 1984 granted American companies the discretion to specify titles and duties for their management team members, the power of the original role has diminished. For instance, CEOs and CFOs are usually responsible for the release of corporate information to the public, General Counsels often act as a liaison between firms and regulators and Chief Compliance Officers have a responsibility to ensure legal compliance. A major difference is that Chinese board secretaries report directly to boards of directors, whereas company secretaries report to General Counsels or CEOs. As Chinese board secretaries undertake legal and regulatory duties and consequently expose themselves to more litigation risks arising from irresponsible forecast disclosure, Chinese board secretaries play a more important role in information disclosure than company secretaries in other countries. Since they report directly to corporate boards, they are expected to safeguard the interests of shareholders.

Management earnings forecasts issued by Chinese listed firms differ from those disclosed by US firms in two ways. First, Chinese firms can decide whether to issue earnings forecasts based on the difference between their current predictions about future earnings and the actual earnings in the corresponding period of the previous year, while

\footnotetext{
${ }^{4}$ Source: http://english.sse.com.cn/laws/framework/ and http://www. szse.cn/main/en/RulesandRegulations/SZSERules/GeneralRules/.
}

American firms make forecast decisions based on the deviation of the market expectations regarding their future earnings from their own predictions. The difference is caused by the underdeveloped role of financial analysts in the Chinese stock market. Second, Chinese listed firms normally issue management forecasts on future net profits, whereas public firms in the USA often issue management forecasts of future earnings per share (EPS).

\section{Literature and Hypothesis Development}

\section{Related Literature}

The literature shows that top managers influence management earnings forecasts. Baik et al. (2011) document the positive relationship between CEO ability and the likelihood, frequency and accuracy of management earnings forecasts. Stock markets respond more strongly to earnings forecasts issued by high-ability CEOs, which suggests that management earnings forecasts communicate information regarding CEOs' ability to the market. Cassell et al. (2013) show that retiring CEOs are more likely to issue earnings forecasts in the final year of their tenure, and those final year forecasts are more likely to contain good news. This result is stronger when CEOs receive high equity holdings and when CEOs cut final year spending in R\&D and capital expenditure, implying that retiring CEOs tend to manage final year earnings forecasts for their self-serving benefits. Kwak et al. (2012) find that Chief Counsels play an important role in forecast disclosures. Firms with a General Counsel in management are more likely to issue earnings forecasts, and their forecasts tend to be less optimistic and more accurate. They further show that the influence of General Counsels on forecast disclosures is more significant when the General Counsel also holds the role of company secretary or receives higher compensation.

The literature also documents the link between management styles and voluntary disclosure of earnings forecasts. Bamber et al. (2010) find that top managers exhibit idiosyncrasies to a significant degree in earnings forecast disclosures. Managers' styles regarding earnings forecast disclosure are associated with their career path, age cohort, military experience, education and legal background. Similarly, Brochet et al. (2011) find that firms hiring new CEOs with previous forecasting experience are more likely to issue earnings forecasts. Among firms that have historically issued earnings forecasts, they document that a temporary break in forecast issuance follows CFO turnover, and that subsequent forecasts disclosed by a newly appointed CFO tend to be less precise, due to the CFO's inexperience in the firm or industry. 
The literature indicates that managers are likely to strategically manage earnings forecasts for their self-serving benefit. Cheng and Lo (2006) report that managers who plan to buy their firm's stocks issue more bad news forecasts to decrease the purchase price, while managers who plan to sell their firm's stocks do not change their forecasting strategy, due to the higher litigation risk associated with insider sales. CEO insider trading has a bigger influence on disclosure than insider trading in general. Likewise, Cheng et al. (2013) find a positive (negative) relationship between forecast news and forecast precision before managers sell (buy) their firm's stocks, suggesting that managers issue good news forecasts with high (low) precision before insider sales (purchases). They also reveal that managers are less inclined to strategically manage forecast precision when large institutional investors exist or when their forecasting behaviour poses great litigation risk, and they are more likely to manage precision when that precision cannot be assessed by investors.

Previous research supports the notion that management earnings forecast outcomes also have implications for individual managers. Trueman (1986) reports that investors use management forecast quality to evaluate managers' ability to adjust production plans according to foreseeable changes in the business environment. Lee et al. (2012) find that inaccurate management earnings forecasts result in the replacement of CEOs in firms with poor earnings performance. This implies that boards of directors in these firms use management earnings forecast accuracy to evaluate CEOs' ability in uncertain business environments when making decisions on CEO replacement. The relation between management earnings forecast accuracy and CEO turnover is more pronounced among firms with less entrenched CEOs.

\section{Hypothesis Development: Expertise}

Research in corporate governance has long focused on the effects of top managers' demographic characteristics on corporate financial performance (Nelson 2005; Kaplan et al. 2012). Bamber et al. (2010) show that top managers' personal characteristics, including age, education and functional experience, influence management earnings forecasts. Since board secretaries are top management team members and are legally responsible for information disclosure by law, we argue that their demographic characteristics affect their competence in improving management forecasts. Specifically, we expect that board secretaries' legal background, accounting background and international experience could influence their firms' earnings forecast policies.
Board secretaries with legal expertise are more sensitive to litigation risks associated with information asymmetry, and they are more likely to have more of an intention to improve, rather than stating it outright. Furthermore, since board secretaries with legal expertise are more capable of advising other managers on issues related to legislative and regulatory compliance, they can in turn improve firms' overall risk management and information disclosure quality. In addition, the issuance of earnings forecasts requires accounting knowledge. Board secretaries with accounting expertise can better understand the financial conditions of firms and more accurately predict future earnings.

International expertise has been identified as an important managerial characteristic. Chinese returnee managers have opportunities to learn about more advanced legal institutions and superior management practices during their overseas experience (Duan and Hou 2016; Cumming et al. 2016a, b). Giannetti et al. (2013) provide evidence that board directors with international experience transfer the advanced governance and management knowledge they acquire abroad to Chinese firms, which leads to the improved corporate governance and earnings performance of those local firms. In addition, managers' international experience is found to improve corporate performance (Carpenter et al. 2001) and corporate social performance (Slater and Dixon-Fowler 2009). Therefore, we expect that Chinese board secretaries with international work or study experience are more likely to enhance the quality of management earnings forecasts, and we propose $\mathrm{H} 1$ as follows.

H1 The expertise of board secretaries (H1a: legal expertise, H1b: accounting expertise, H1c: international expertise) increases the quality of management earnings forecasts.

\section{Hypothesis Development: Political Connections}

Politically connected managers in China have been found to undermine firm performance (Fan et al. 2007) because they lack business experience and tend to pursue social objectives rather than maximising shareholder interest. In addition, political connection brings privileges, such as job security. In other words, it increases managerial entrenchment and undermines managers' accountability (Cao et al. 2011; You and Du 2012). We therefore expect that politically connected board secretaries are less capable of issuing high-quality forecasts, and we propose $\mathrm{H} 2$ as follows.

H2 The political connection of board secretaries decreases the quality of management earnings forecasts. 


\section{Hypothesis Development: Role Duality}

Finkelstein (1992) measures the structural power of managers by the number of official titles that they hold. He notes that top managers' ability to influence corporate decisions is contingent on their power. We argue that board secretaries holding other senior executive titles are able to access more resources to provide high-quality management earnings forecasts. Board secretaries often take on an additional post of board director, $\mathrm{CFO}$ or another senior executive role (e.g. vice-president). ${ }^{5}$

In terms of the additional roles, first, board directorship could align the interests of board secretaries with shareholders and consequently enhance forecast quality. Organisation theory suggests that the consolidation of management and board roles promotes unity of command and leads to organisational effectiveness (Pfeffer and Salancik 1978; Donaldson and Davis 1991; Boyd 1990, 1995). Second, board secretaries who are also CFOs have greater financial insight and can use this information advantage to issue more accurate forecasts. Third, board secretaries who hold other senior executive positions, such as presidents and vice-presidents, tend to be extensively involved in daily management and operation. Such experience and power help to enhance management earnings forecasts. We hereby propose $\mathrm{H} 3$ as follows:

H3 The role duality of board secretaries (H3a: board member, H3b: CFO, H3c: other senior executive role) increases the quality of management earnings forecasts.

\section{Hypothesis Development: Equity Holdings}

Producing high-quality forecasts can be costly, and board secretaries may choose to withhold information instead. Jensen and Meckling (1976) and Datta et al. (2005) point out that managerial equity holdings can alleviate agency problems and facilitate managers' incentive alignment with investors (Jensen and Meckling 1976; Datta et al. 2005). Nagar et al. (2003) find that CEOs tend to provide more frequent management earnings forecasts when the interests of CEOs and shareholders are aligned. Thus, we argue that board secretaries' equity holdings motivate them to reduce information asymmetry by issuing high-quality management earnings forecasts.

H4 The equity holding of board secretaries increases the quality of management earnings forecasts.

\footnotetext{
5 The literature documents the influence of CEOs, CFOs and General Counsels on management earnings forecasts (Bamber et al. 2010; Brochet et al. 2011; Baik et al. 2011; Kwak et al. 2012; Cassell et al. 2013).
}

\section{Data and Research Design}

\section{Sample Selection}

We hand-collect data on board secretary characteristics from their biographical information in the China Securities Market and Accounting Research (CSMAR) database for all listed firms on the Main Board of the Shenzhen Stock Exchange between 2001 and 2012. ${ }^{6}$ We obtain management earnings forecast data from the RESSET database. We use both quarterly and annual management earnings forecasts. Following Anilowski et al. (2007), we require that a quarterly management forecast is issued prior to the earnings announcement date of the forecast fiscal quarter and no more than 90 days prior to the end of that fiscal quarter. For annual forecasts, we require that the forecast is issued prior to the earnings announcement date of the forecast fiscal year and no more than 730 days prior to the end of that fiscal year.

Table 1A summarises the definition and data sources of all variables. After merging the management forecast data with data on board secretary characteristics, corporate governance and firm characteristics, the final sample contains 6840 firm-year observations to conduct management forecast occurrence and frequency analyses. The sample contains 5362 firm-years that have at least one management forecast issuance; these are used to analyse management forecast precision. When we examine management forecast accuracy and optimism, the sample size is further reduced to 4818 firm-years due to the availability of data on actual earnings and stock prices.

\section{Empirical Model}

To examine the impact of board secretary characteristics on the properties of management earnings forecasts, we use the following regression model:

$$
\begin{aligned}
\text { ForecastProperty }_{i, t+1}= & \beta_{0}+\beta_{1} \text { Expertise }_{i . t}+\beta_{2} \text { PartyMeb }_{i . t} \\
& +\beta_{3} \text { Duality }_{i . t}+\beta_{4} \text { EquityHold }_{i . t} \\
& +\sum \beta_{k} \text { Controls }_{k, i, t}+\varepsilon_{i, t+1}
\end{aligned}
$$

where $i$ indexes firm and $t$ indexes year. Forecast is one of the management forecast properties: Occurrence, Frequency, Precision, Accuracy and Optimism. Occurrence is a dummy variable which is equal to one if there is at least

\footnotetext{
${ }^{6}$ Due to the workload of hand-collecting data, we only include firms listed on the Shenzhen Stock Exchange. We do not see any reason to expect that the role of board secretaries in the Shanghai Stock Exchange would be different. The sample starts from 2002 because management earnings forecast data is available from 2002 in the RESSET database.
} 
one management forecast issuance in a given firm-year, and zero otherwise. Frequency is the total number of forecasts issued by a firm in a given year. Precision is coded as three if the forecast is a point forecast, two if it is a range forecast, one if it is an open-interval forecast and zero if it is a qualitative forecast. Accuracy is the absolute difference between the management forecast of net profits and the actual net profits, scaled by the market value of tradable shares one day prior to the forecast release date, and then multiplied by -1 . A less negative value of $A c$ curacy indicates higher management forecast accuracy. Optimism is coded as 1 if the management earnings forecast is higher than the actual net profits (optimistic bias), 0 if it is equal to the actual net profits, and -1 if it is less than the actual net profits (pessimistic bias). When firms issue multiple forecasts in a year, we take their average values to construct Precision, Accuracy and Optimism. We use point, range and open-interval forecasts to construct Accuracy and Optimism. For range forecasts, the midpoint of the range is used as the management forecast estimate (Kross et al. 2011). For open-interval forecasts, the value provided in the open-interval forecast is taken as the management forecast estimate (Yang 2012; Cassell et al. 2013).

We examine whether and how the properties of management earnings forecasts are affected by board secretary characteristics, including professional background, political connections, role duality and equity holdings. We construct three background variables for Expertise. Law is a dummy variable, equal to one if a board secretary holds a law licence, and zero otherwise. Accounting is a dummy variable, equal to one if a board secretary holds a professional certificate in accounting, and zero otherwise. ForeignExp is coded as 1 if a board secretary has work or study experience in foreign countries, 0.5 if she/he has work experience in Hong Kong, Macau or Taiwan, and 0 otherwise. Following $\mathrm{Li}$ et al. (2008), we use Chinese
Communist Party membership to measure the political connection of board secretaries. PartyMeb is a binary indicator suggesting the existence of a board secretary's political connection, which equals one if the secretary is a member of the Chinese Communist Party, and zero otherwise.

We also examine three forms of board secretary duality. Duality is proxied by Board_Duality, CFO_Duality and Mag_Duality. Board_Duality is a dummy variable, equal to one if a board secretary is a member of the firm's board of directors, and zero otherwise. CFO_Duality is a dummy variable, equal to one if a board secretary serves as the firm's CFO, and zero otherwise. Mag_Duality is a dummy variable, equal to one if a board secretary holds an additional non-accounting senior executive position in the firm, and zero otherwise. Finally, we examine the effect of the equity holdings of board secretaries on management forecast properties. The equity holdings of board secretaries are calculated as the change in value of the secretary's stockholdings given a $1 \%$ increase in the firm's stock prices (Bergstresser and Philippon 2006; Burns and Kedia 2006). EquityHold is defined as the natural logarithm of one plus the equity holdings.

In our regressions, we control for other board secretary demographic characteristics. Female is a dummy variable, equal to one if a board secretary is female, and zero otherwise. Age is the age of a board secretary. Ln(Tenure) is the natural logarithm of the number of days that a board secretary has held this position. If the board secretary was replaced during a firm-year, we use the characteristics of the board secretary holding the position at the year-end to construct these variables.

We also control for corporate governance characteristics, as prior research finds evidence suggesting that better corporate governance improves management forecast quality (Karamanou and Vafeas 2005; Ajinkya et al. 2005).

Table 2 Descriptive statistics on management earnings forecasts

\begin{tabular}{|c|c|c|c|c|c|c|c|c|c|c|c|}
\hline & \multicolumn{3}{|c|}{ Annual forecasts } & \multicolumn{3}{|c|}{ Quarterly forecasts } & \multicolumn{3}{|c|}{ Overall forecasts } & \multirow{2}{*}{$\begin{array}{l}\text { Difference in } \\
\text { mean (annual- } \\
\text { quarterly) }\end{array}$} & \multirow{2}{*}{$\begin{array}{l}\text { Difference in } \\
\text { median (annual- } \\
\text { quarterly) }\end{array}$} \\
\hline & Mean & Median & SD & Mean & Median & SD & Mean & Median & $\mathrm{SD}$ & & \\
\hline Precision & 2.115 & 2.000 & 0.491 & 2.122 & 2.000 & 0.484 & 2.119 & 2.000 & 0.486 & $-0.007(-0.85)$ & $0.000(-0.79)$ \\
\hline Accuracy & -30.208 & -6.286 & 194.423 & -8.409 & -2.204 & 33.356 & -15.820 & -3.151 & 117.000 & $\begin{array}{c}-21.799 * * * \\
(-10.78)\end{array}$ & $\begin{array}{r}-4.081 * * * \\
(-35.22)\end{array}$ \\
\hline Optimism & 0.093 & 1.000 & 0.996 & -0.049 & -1.000 & 0.999 & -0.001 & -1.000 & 1.000 & $0.142 * * *(8.23)$ & $2.000 * * *(8.21)$ \\
\hline Horizon & 128.531 & 142.000 & 63.114 & 59.553 & 60.000 & 39.384 & 83.010 & 73.000 & 58.700 & $\begin{array}{c}68.978 * * * \\
(81.65)\end{array}$ & $\begin{array}{c}82.000 * * * \\
(65.58)\end{array}$ \\
\hline \#Obs. & 9801 & & & 5049 & & & 14,850 & & & & \\
\hline
\end{tabular}

This table presents descriptive statistics for management earnings forecasts issued during 2002-2012. The $t$ statistics for difference in mean and the Wilcoxon $z$-statistics for difference in median are presented in brackets. *** denotes statistical significance at the $1 \%$ level. Variable definitions are provided in Table A.1 
Table 3 Descriptive statistics on variables

\begin{tabular}{|c|c|c|c|c|c|c|c|c|}
\hline Variable & \#Obs. & Mean & SD & Min & $\mathrm{P} 25$ & Median & P75 & Max \\
\hline \multicolumn{9}{|c|}{ Annual Management Forecasts } \\
\hline Occurrence & 6840 & 0.654 & 0.476 & 0.000 & 0.000 & 1.000 & 1.000 & 1.000 \\
\hline Frequency & 6840 & 0.850 & 0.750 & 0.000 & 0.000 & 1.000 & 1.000 & 3.000 \\
\hline Precision & 4471 & 1.827 & 0.804 & 0.000 & 2.000 & 2.000 & 2.000 & 3.000 \\
\hline Accuracy & 3839 & -21.150 & 45.070 & -311.700 & -18.360 & -6.511 & -2.387 & -0.054 \\
\hline Optimism & 3839 & 0.077 & 0.946 & -1.000 & -1.000 & 0.000 & 1.000 & 1.000 \\
\hline Ln(Horizon) & 4462 & 4.759 & 0.530 & 2.398 & 4.549 & 4.916 & 5.112 & 5.609 \\
\hline $\operatorname{Pr}($ BadNews $)$ & 6492 & 0.222 & 0.416 & 0.000 & 0.000 & 0.000 & 0.000 & 1.000 \\
\hline \#BadNews & 6492 & 0.247 & 0.489 & 0.000 & 0.000 & 0.000 & 0.000 & 3.000 \\
\hline$\%$ BadNews & 6492 & 0.214 & 0.405 & 0.000 & 0.000 & 0.000 & 0.000 & 1.000 \\
\hline \multicolumn{9}{|c|}{ Quarterly Management Forecasts } \\
\hline Occurrence & 6840 & 0.720 & 0.449 & 0.000 & 0.000 & 1.000 & 1.000 & 1.000 \\
\hline Frequency & 6840 & 1.680 & 1.298 & 0.000 & 0.000 & 2.000 & 3.000 & 5.000 \\
\hline Precision & 4922 & 1.837 & 0.776 & 0.000 & 2.000 & 2.000 & 2.000 & 3.000 \\
\hline Accuracy & 4267 & -7.259 & 14.040 & -105.800 & -7.264 & -2.863 & -1.070 & -0.018 \\
\hline Optimism & 4267 & -0.053 & 0.846 & -1.000 & -1.000 & 0.000 & 1.000 & 1.000 \\
\hline Ln(Horizon) & 4906 & 3.984 & 0.649 & 1.792 & 3.738 & 4.190 & 4.511 & 4.736 \\
\hline \multicolumn{9}{|c|}{ All Management Forecasts } \\
\hline Occurrence & 6840 & 0.787 & 0.410 & 0.000 & 1.000 & 1.000 & 1.000 & 1.000 \\
\hline Frequency & 6840 & 2.533 & 1.800 & 0.000 & 1.000 & 3.000 & 4.000 & 7.000 \\
\hline Precision & 5380 & 1.817 & 0.771 & 0.000 & 1.750 & 2.000 & 2.000 & 3.000 \\
\hline Accuracy & 4829 & -13.340 & 27.530 & -192.900 & -12.270 & -4.818 & -1.846 & -0.048 \\
\hline Optimism & 4829 & -0.026 & 0.787 & -1.000 & -1.000 & 0.000 & 1.000 & 1.000 \\
\hline Ln(Horizon) & 5365 & 4.279 & 0.603 & 2.197 & 4.069 & 4.477 & 4.694 & 5.201 \\
\hline \multicolumn{9}{|c|}{ Board Secretary Characteristics } \\
\hline Law & 6840 & 0.020 & 0.139 & 0.000 & 0.000 & 0.000 & 0.000 & 1.000 \\
\hline Accounting & 6840 & 0.163 & 0.369 & 0.000 & 0.000 & 0.000 & 0.000 & 1.000 \\
\hline ForeignExp & 6840 & 0.035 & 0.169 & 0.000 & 0.000 & 0.000 & 0.000 & 1.000 \\
\hline PartyMeb & 6840 & 0.323 & 0.468 & 0.000 & 0.000 & 0.000 & 1.000 & 1.000 \\
\hline Board_Duality & 6840 & 0.269 & 0.443 & 0.000 & 0.000 & 0.000 & 1.000 & 1.000 \\
\hline CFO_Duality & 6840 & 0.082 & 0.274 & 0.000 & 0.000 & 0.000 & 0.000 & 1.000 \\
\hline Mag_Duality & 6840 & 0.408 & 0.492 & 0.000 & 0.000 & 0.000 & 1.000 & 1.000 \\
\hline EquityHold & 6834 & 2.086 & 3.942 & 0.000 & 0.000 & 0.000 & 0.000 & 13.800 \\
\hline Female & 6840 & 0.177 & 0.382 & 0.000 & 0.000 & 0.000 & 0.000 & 1.000 \\
\hline Age & 6840 & 40.550 & 7.010 & 23.000 & 35.000 & 40.000 & 45.000 & 71.000 \\
\hline Ln(Tenure) & 6840 & 6.939 & 1.059 & 3.091 & 6.433 & 7.170 & 7.687 & 8.490 \\
\hline Ln(Pay) & 4439 & 12.090 & 0.846 & 9.879 & 11.520 & 12.120 & 12.660 & 14.130 \\
\hline Turnover & 5398 & 0.142 & 0.349 & 0.000 & 0.000 & 0.000 & 0.000 & 1.000 \\
\hline \multicolumn{9}{|c|}{ Firm Characteristics } \\
\hline BIndep & 6840 & 0.335 & 0.091 & 0.000 & 0.333 & 0.333 & 0.375 & 0.556 \\
\hline InstHold & 6840 & 0.170 & 0.189 & 0.000 & 0.021 & 0.096 & 0.265 & 0.742 \\
\hline GovHold & 6840 & 0.188 & 0.239 & 0.000 & 0.000 & 0.014 & 0.383 & 0.750 \\
\hline $\mathrm{CR}$ & 6840 & 0.584 & 0.150 & 0.229 & 0.477 & 0.603 & 0.704 & 0.868 \\
\hline Duality & 6840 & 0.203 & 0.402 & 0.000 & 0.000 & 0.000 & 0.000 & 1.000 \\
\hline BMeet & 6840 & 8.525 & 3.249 & 3.000 & 6.000 & 8.000 & 10.000 & 20.000 \\
\hline $\mathrm{P} / \mathrm{B}$ & 6840 & 4.060 & 3.769 & -5.750 & 1.970 & 3.125 & 5.000 & 24.340 \\
\hline Ln(Assets) & 6840 & 21.280 & 1.061 & 18.820 & 20.570 & 21.170 & 21.890 & 24.540 \\
\hline MBE & 3328 & 0.401 & 0.490 & 0.000 & 0.000 & 0.000 & 1.000 & 1.000 \\
\hline
\end{tabular}


Table 3 continued

\begin{tabular}{lcccrrrrr}
\hline Variable & \#Obs. & Mean & SD & Min & P25 & Median & P75 & Max \\
\hline CMBE & 2512 & 0.195 & 0.396 & 0.000 & 0.000 & 0.000 & 0.000 & 1.000 \\
Firm-Level Outcomes & & & & & & & \\
MAO & 5773 & 0.081 & 0.273 & 0.000 & 0.000 & 0.000 & 0.000 & 1.000 \\
SUE & 4829 & 0.060 & 0.237 & 0.000 & 0.000 & 0.000 & 0.000 & 1.000 \\
Donation & 4084 & 1.496 & 4.394 & 0.000 & 0.000 & 0.000 & 0.000 & 19.600 \\
CSR_Disclose & 4084 & 0.219 & 0.414 & 0.000 & 0.000 & 0.000 & 0.000 & 1.000 \\
CapExp & 5730 & 0.390 & 0.616 & -0.939 & 0.065 & 0.215 & 0.509 & 3.900 \\
Opacity & 6172 & 0.118 & 0.189 & 0.001 & 0.024 & 0.057 & 0.122 & 1.205 \\
ROA & 6830 & 0.036 & 0.065 & -0.168 & 0.010 & 0.034 & 0.067 & 0.177 \\
ROS & 6817 & 0.050 & 0.177 & -0.675 & 0.017 & 0.054 & 0.117 & 0.396 \\
Tobin's Q & 6823 & 2.267 & 1.457 & 0.896 & 1.282 & 1.767 & 2.675 & 7.108 \\
\hline
\end{tabular}

This table presents descriptive statistics for the management earnings forecasts, board secretary characteristics, firm characteristics and firm-level outcome variables used in our regressions. Variable definitions are provided in Table A.1

We consider several corporate governance factors. BIndep is the proportion of independent directors on the board. BMeet is the number of board meetings. Duality is a binary variable which equals one if a CEO also serves as the chair of the board, and zero otherwise. InstHold is the proportion of shares held by institutional investors. GovHold is the proportion of shares held by the Chinese government. In addition, the model controls for a number of firm-level characteristics. ${ }^{7}$ Since Ajinkya et al. (2005) find a negative relation between ownership concentration and management forecast properties, we control for the concentration ratio $(C R)$, which is measured as the proportion of stocks held by the firm's ten largest blockholders. The price-to-book ratio $(P / B)$ is included to account for a firm's growth

\footnotetext{
7 We also control for the meeting or beating earnings expectations (MBE) and consistency in meeting or beating earnings expectations (CMBE), because prior studies find that managers issue management forecasts to meet or beat the market's expectations (MBE), and this tendency is stronger when firms have consistently met or beaten the market's expectations (Matsumoto 2002; Kross et al. 2011). Following Kross et al. (2011), we construct two control variables for firms' MBE record: (1) $M B E$ is a dummy variable with a value equal to one if a firm's actual earnings meet or beat the most recent consensus analyst forecast, and zero otherwise; and (2) CMBE is a dummy variable with a value equal to one if a firm's actual earnings meet or beat the most recent consensus analyst forecast for the past two consecutive years, and zero otherwise. Thus, we control the MBE and CMBE in Tables 3, 4, 5, 6 and 7 as further additional tests in our Unpublished Appendix. The results are broadly consistent. We thank the referee for this suggestion. It is worth noting that by incorporating $\mathrm{MBE}$ and $\mathrm{CMBE}$ in the regression model, we lose 51 and $63 \%$ of our observations, respectively. This is because analyst earnings forecast data is only available for annual earnings from 2002, and analysts' earnings forecasts are not prevalent either. Table 2 reports the observations of MBE and CMBE.
}

opportunities; Bamber and Cheon (1998) find that growth opportunities serving as an indicator of proprietary costs are related to firms' forecasting choices. Ln(Assets) is calculated as the natural logarithm of a firm's total assets and is included in our model because firm size has been found to affect forecast disclosures (Kasznik and Lev 1995; Baginski and Hassell 1997). We also control for Crisis, which is a dummy variable with a value equal to one if the forecast year is during the crisis period of 2007-2008, and zero otherwise. Moreover, the literature on voluntary information disclosure suggests that firms in different industries are exposed to different litigation costs, proprietary costs and information asymmetry and thus manage their forecasting policies using different strategies (Kasznik and Lev 1995; Bamber and Cheon 1998). Therefore, we include Industry dummies, defined as the first two digits of the firm's Global Industry Classification Standard (GICS) code.

We estimate Eq. (1) using a Probit model if the dependent variable is Occurrence, a Poisson model if the dependent variable is Frequency, and an ordinary least squares (OLS) regression if the dependent variable is Precision, Accuracy or Optimism. For the regressions of Precision, Accuracy and Optimism, we add an additional control variable, Ln(Horizon), which is the natural logarithm of the number of days between the forecast release date and the actual earnings announcement date. Ln(Horizon) is included because the literature has found a negative relation between forecast horizon and forecast precision and accuracy (Pownall et al. 1993; Baginski and Hassell 1997; Xu 2010). If multiple forecasts are issued in a firm-year, we take the average horizon to generate this 


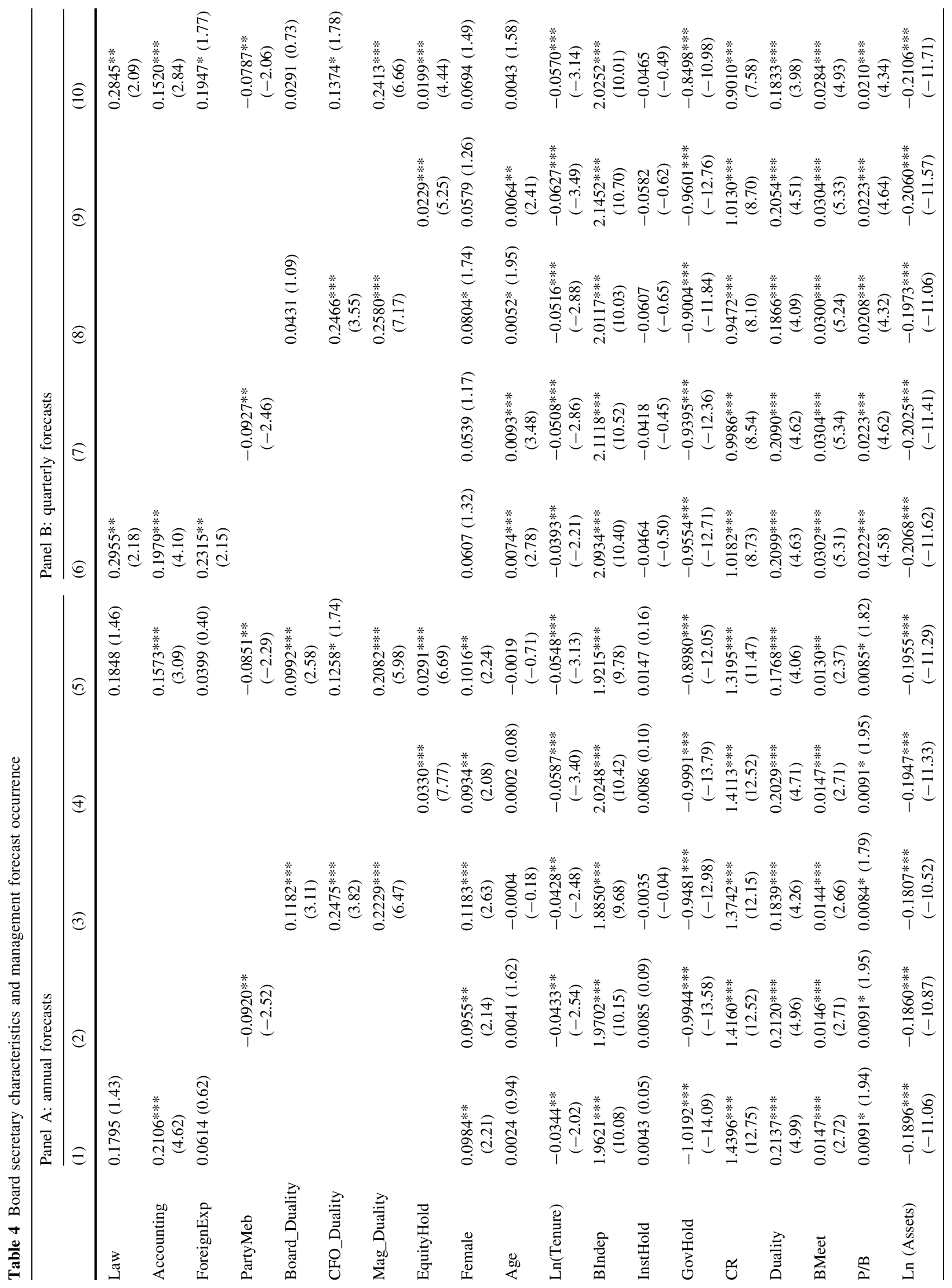




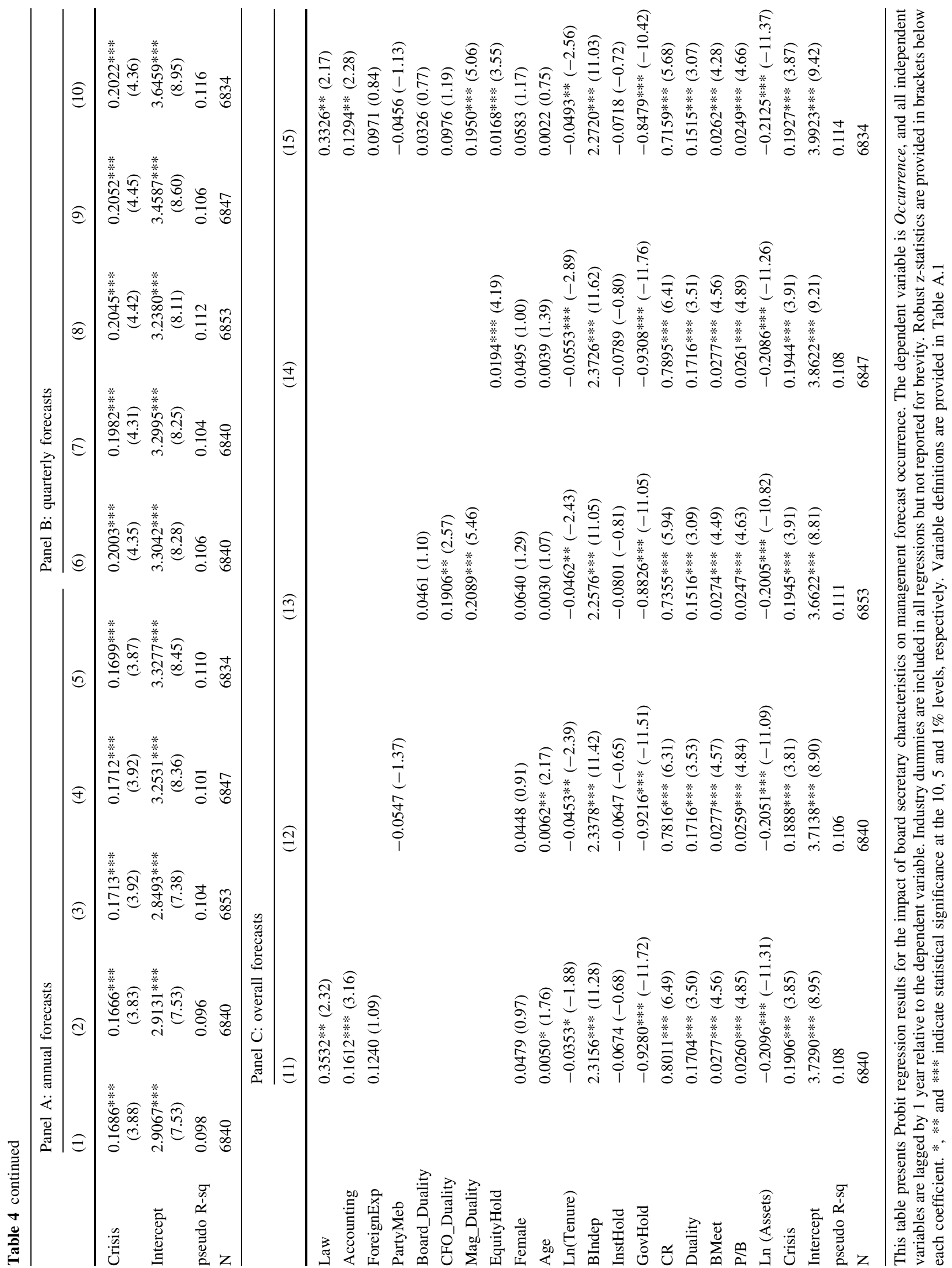


variable. On the right side of Eq. (1), the independent variables, except Ln(Horizon), are lagged by 1 year relative to the dependent variable to mitigate reverse causality. We winsorize all continuous variables at $1 \%$ and $99 \%$.

\section{Descriptive Statistics}

Table 2 presents descriptive statistics on management earnings forecasts by classifying the management forecasts into annual and quarterly forecasts. The difference in mean and median tests shows that there is no obvious difference in forecast precision between the two types of forecasts. The annual forecasts are substantially higher (lower) than the quarterly forecasts in terms of forecast optimism and horizon (forecast accuracy), according to both the difference in mean and the difference in median.

Table 3 presents descriptive statistics for the variables used in our empirical analyses. The mean of Occurrence is $0.654,0.720$ and 0.787 for annual forecasts, quarterly forecasts and overall forecasts, respectively, suggesting that $65.4,72$ and $78.7 \%$ of firm-year observations have at least one forecast issuance for annual forecasts, quarterly forecasts and overall forecasts, respectively. The mean forecasting frequency is $0.850,1.680$ and 2.533 for annual forecasts, quarterly forecasts and overall forecasts, respectively, which indicates the prevalence of multiple forecast disclosures by Chinese firms. The 25th percentile of forecasting precision is $2.00,2.00$ and 1.75 for, respectively, annual forecasts, quarterly forecasts and overall forecasts, suggesting a high propensity of Chinese firms to issue quantitative forecasts. The median forecasting accuracy is -4.818 for overall forecasts, while the mean accuracy for overall forecasts surprisingly reaches -13.340 . These results reveal that there is a high discrepancy in management forecast accuracy and that the forecasts issued by certain firms or in certain years could be extremely unreliable. The mean Optimism $(-0.026$ for overall forecasts) is a negative value, consistent with the idea that management forecasts, on average, are pessimistically biased in China.

We find that lots of board secretaries have a certificate in accounting or serve as a Party member in our sample even though overall it is rare for secretaries to have a law licence or have either foreign experience. In addition, more than half of board secretaries hold another senior role in Chinese listed firms; most hold another non-accounting management position. Over $75 \%$ of board secretaries do not have any equity holdings in their firms.

\section{Empirical Results}

\section{Board Secretary Characteristics and Management Forecast Occurrence}

We examine the effects of board secretaries' professional background, political connections, role duality and equity holdings on management forecast occurrence by using annual forecasts, quarterly forecasts and overall forecasts. The results are shown in Table 4. Panels A, B and C show results for testing of $\mathrm{H} 1, \mathrm{H} 2, \mathrm{H} 3$ and $\mathrm{H} 4$ by using annual forecast occurrence, quarterly forecast occurrence and overall forecast occurrence, respectively. Models 5, 10 and 15 report the results for testing all hypotheses together using annual forecasts, quarterly forecasts and overall forecasts, respectively. The coefficients of Law are significantly positive in models $6,10,11$ and 15 , indicating that board secretaries with legal expertise tend to issue quarterly earnings forecasts. The coefficients of Accounting are significantly positive in models $1,5,6,10,11$ and 15 , indicating that board secretaries with accounting expertise are more likely to issue both annual and quarterly earnings forecasts. The coefficient of ForeignExp is significantly positive in models 6 and 10, indicating that board secretaries with international experience are more likely to issue quarterly annual forecasts. The results generally support the prediction that board secretaries with more expertise are more likely to issue management forecasts, supporting our H1a, 1b and 1c. The coefficient on PartyMeb is significantly negative in models $2,5,7$ and 10 at the $5 \%$ level, which provides evidence of the adverse effect of political connections on both annual and quarterly earnings forecast issuance and supports our H2. In models 3, 5, 8, 10, 13 and 15, we show that the coefficients on Board_Duality, CFO_Duality and Mag_Duality are positively significant. The results suggest that board secretaries sitting on the board are more likely to issue annual earnings forecasts and that board secretaries with a dual CFO or other senior manager title are more likely to issue both annual and quarterly earnings forecasts. Overall, board secretaries with a second senior position generally have more power and more inside information to issue earnings forecasts; this supports our H3a, $3 \mathrm{~b}$ and $3 \mathrm{c}$. Finally, the coefficient on EquityHold is significantly positive in models 4, 5, 9, 10, 14 and 15 , at the $1 \%$ level, which indicates that board secretaries with stockholdings in their firms are more likely to voluntarily disclose both annual and quarterly earnings forecasts for the sake of outside investors. The evidence supports our $\mathrm{H} 4$. 


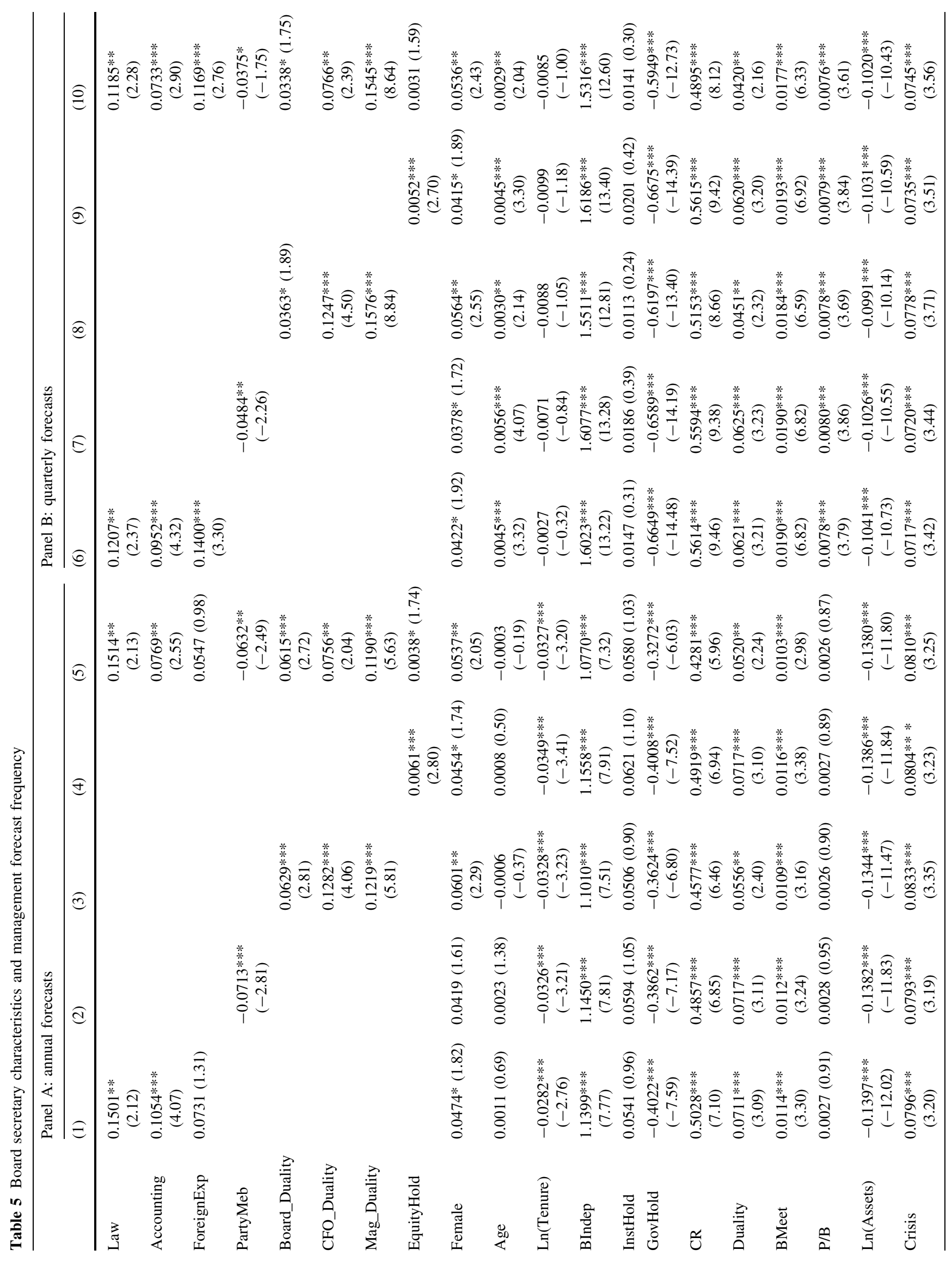




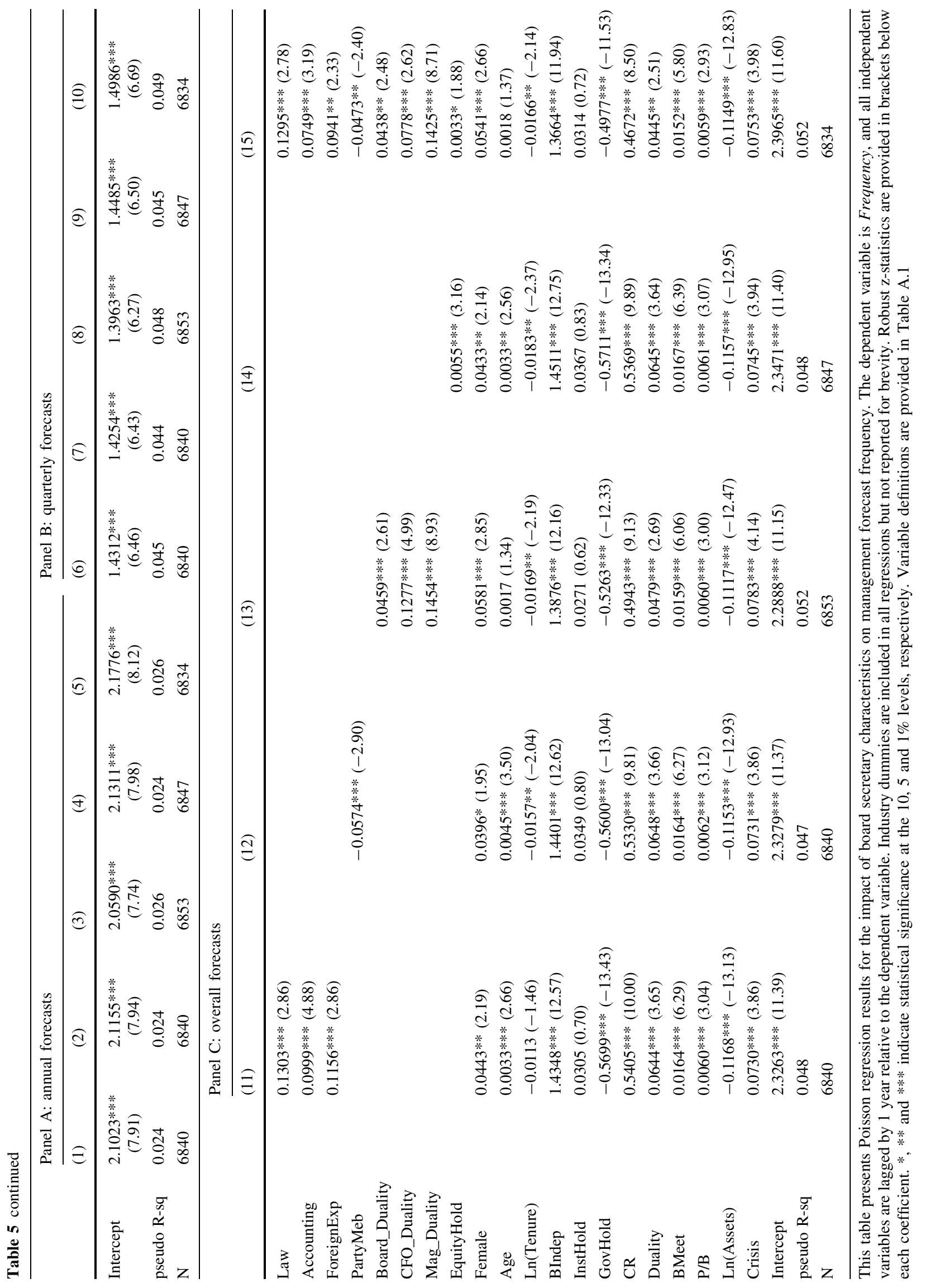




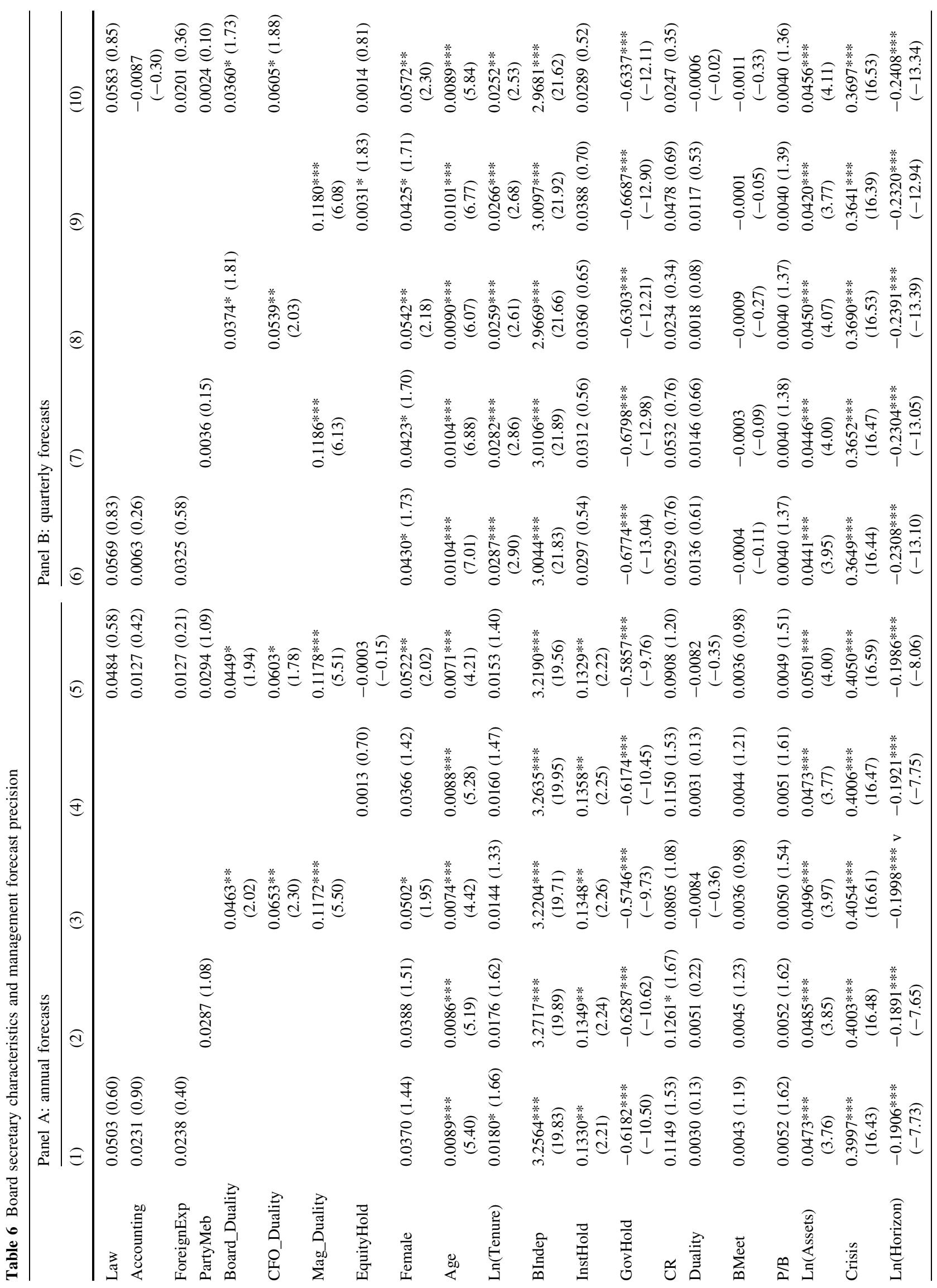




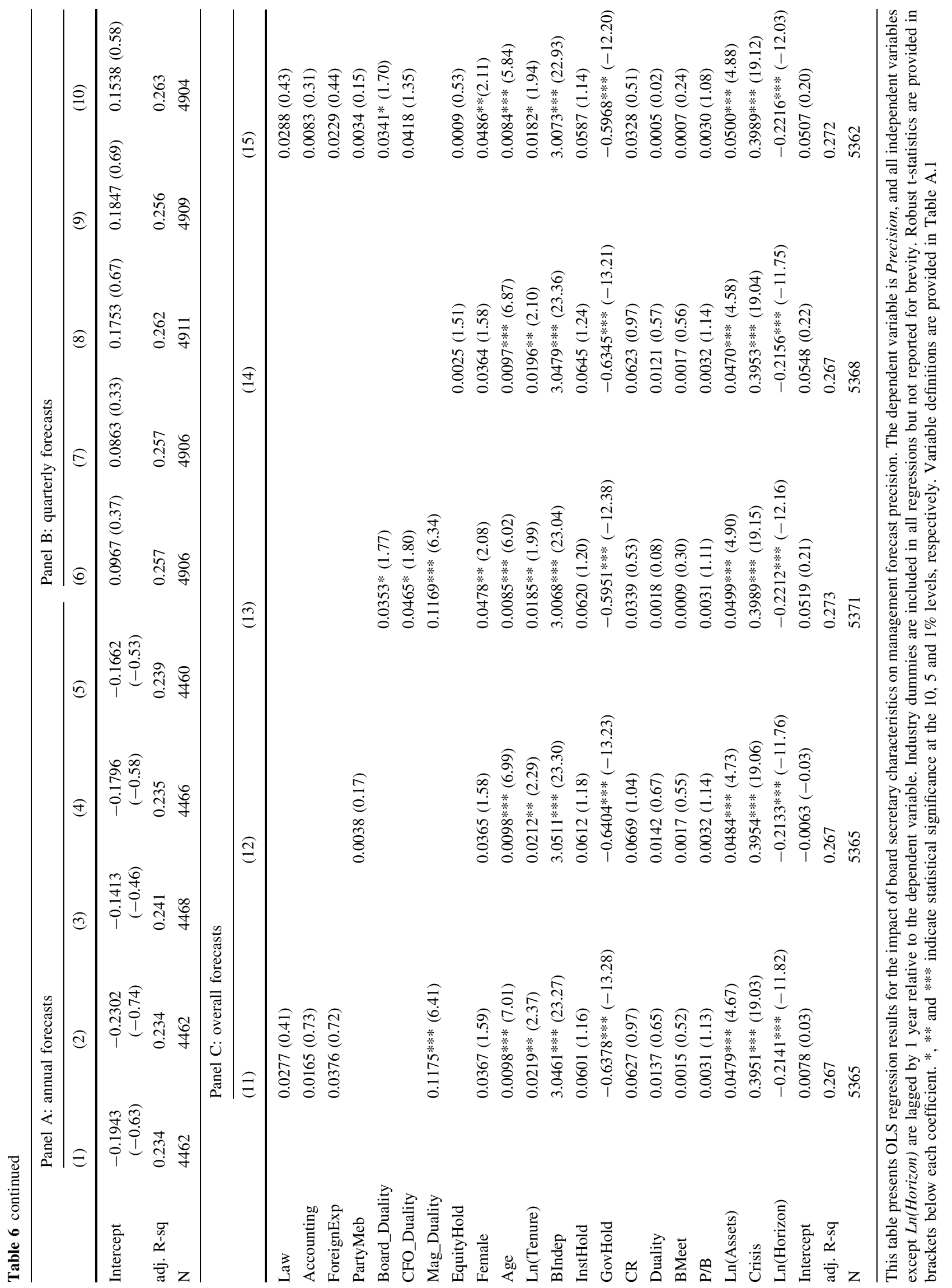




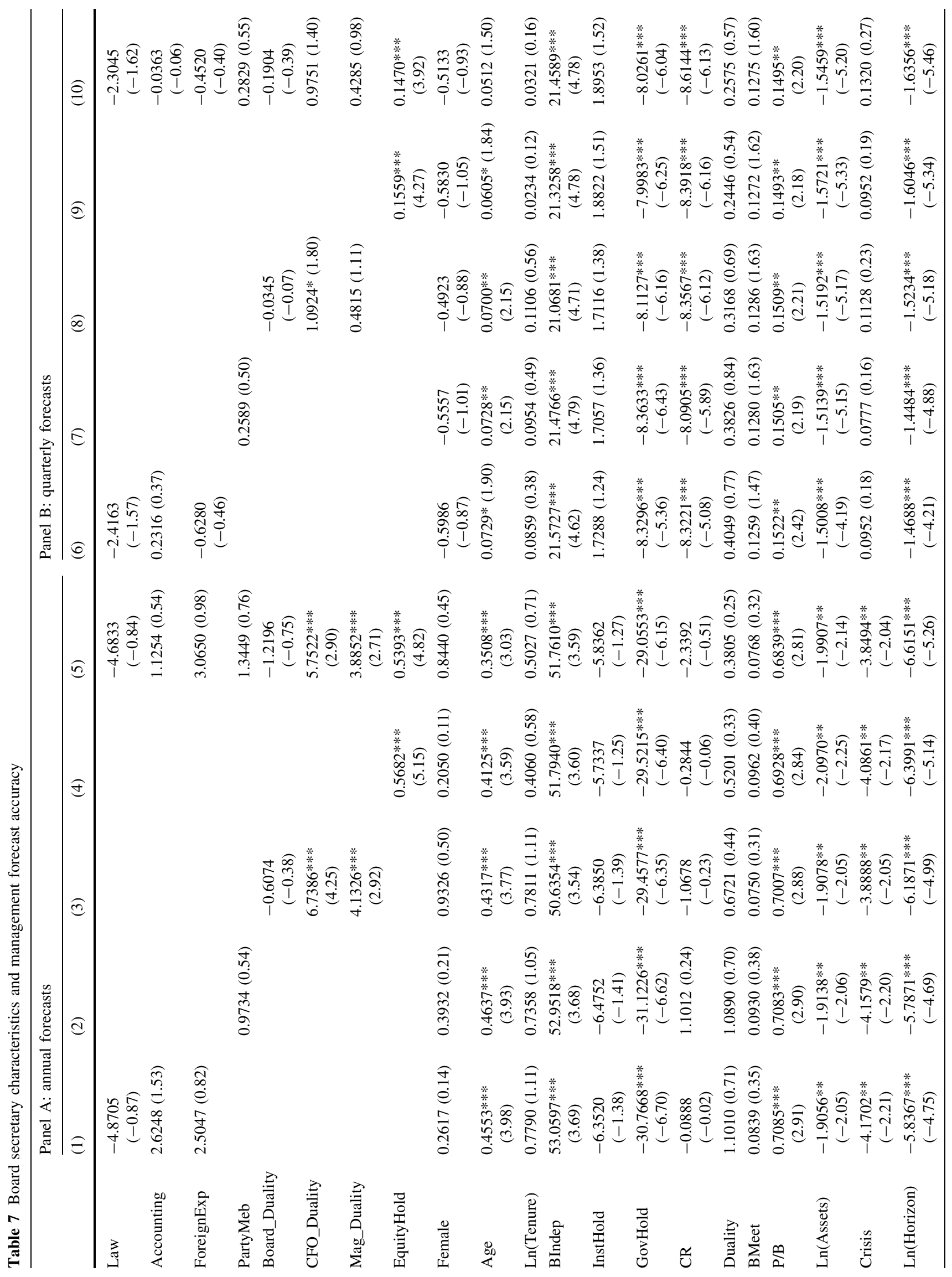




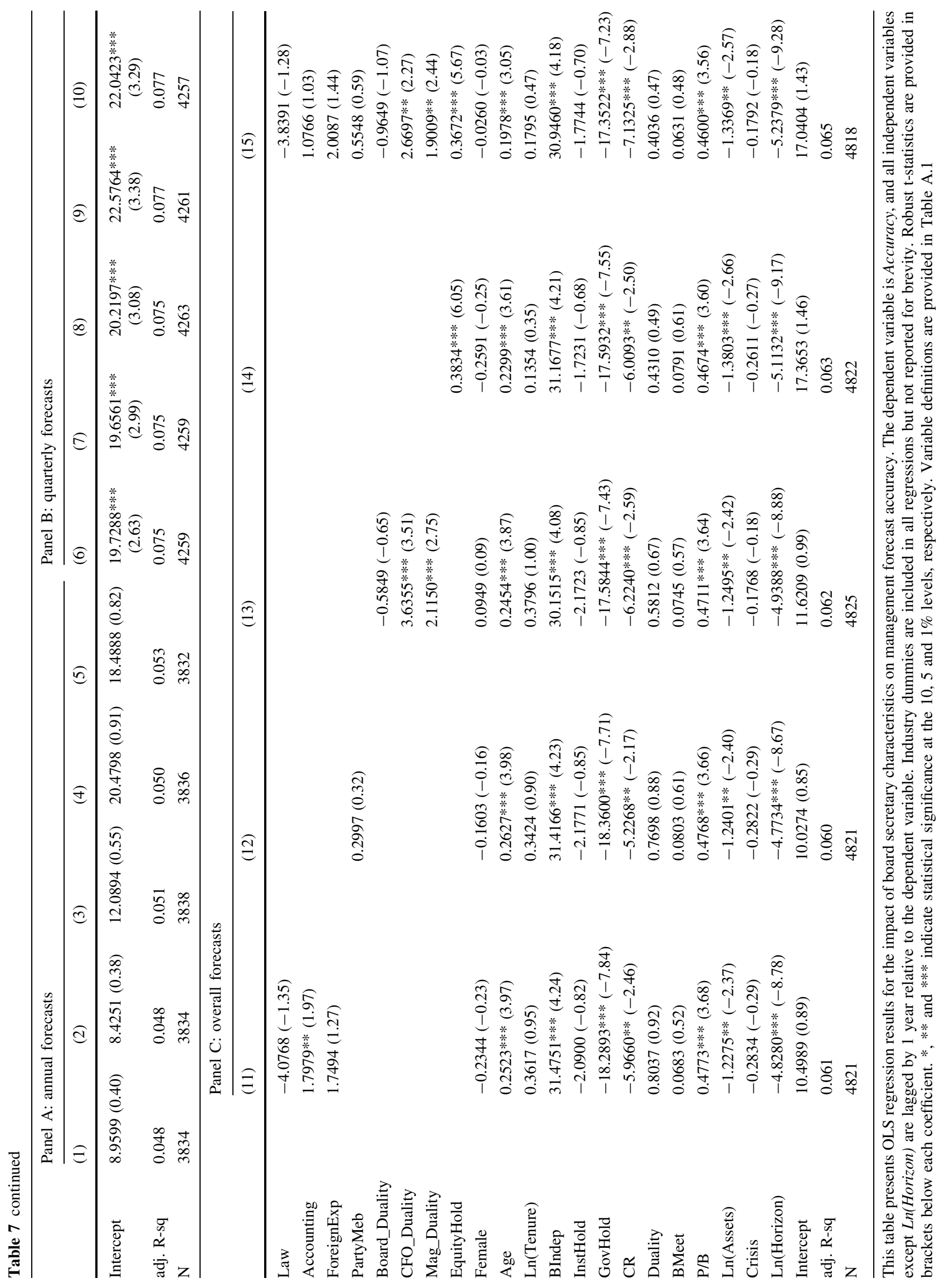




\section{Board Secretary Characteristics and Management Forecast Frequency}

Table 5 reports the test results for the effects of board secretaries' professional background, political connections, dual roles and equity holdings on management forecast frequency. Panels A, B and C show results for testing of $\mathrm{H} 1, \mathrm{H} 2$, H3 and H4 by using annual forecast frequency, quarterly forecast frequency and overall forecast frequency, respectively. It shows that Law, Accounting and ForeignExp are significantly and positively associated with forecast frequency in models 1, 5, 6, 10, 11 and 15, which indicates that the professional expertise of board secretaries improves earnings forecast frequency, supporting H1a, $1 \mathrm{~b}$ and $1 \mathrm{c}$. The coefficient of PartyMeb is significantly negative in all models. The results suggest that political connections decrease board secretaries' willingness to make frequent annual and quarterly forecast disclosures and support $\mathrm{H} 2$. Furthermore, the coefficient estimates on Board_Duality, CFO_Duality and Mag_Duality are significantly positively related to forecast frequency in all models, indicating that board secretary role duality leads to more frequent annual and quarterly forecast issuance. This evidence supports $\mathrm{H} 3 \mathrm{a}$, $3 \mathrm{~b}$ and $3 \mathrm{c}$. The coefficient estimates on EquityHold are significantly positive in all models, which support $\mathrm{H} 4$, about the positive incentive role of board secretaries' stockholdings for both annual and quarterly forecast frequency.

\section{Board Secretary Characteristics and Management Forecast Precision}

Table 6 provides the test results for the effects of board secretaries' professional background, political connections, role duality and equity holdings on management forecast precision. Panels A, B and $\mathrm{C}$ show results for testing of $\mathrm{H} 1$, $\mathrm{H} 2$, H3 and H4 by using annual forecast precision, quarterly forecast precision and overall forecasts precision, respectively. The coefficient estimates on Board_Duality, CFO_Duality and Mag_Duality are significantly positive on both annual and quarterly forecast precision in all models. This result suggests that board secretaries with role duality employ their expanded power and superior resources to generate more precise earnings forecasts, which supports $\mathrm{H} 3 \mathrm{a}, 3 \mathrm{~b}$ and $3 \mathrm{c}$. In addition, the result shows that EquityHold significantly improves the precision of quarterly earnings forecasts and supports $\mathrm{H} 4$.

\section{Board Secretary Characteristics and Management Forecast Accuracy}

As for the accuracy of management forecasts, we examine its association with board secretary characteristics from two ways: the value (Accuracy) and the sign (Optimism). In
Table 7, we present the results for the associations between board secretary characteristics and forecast Accuracy. Panels A, B and C show results for testing of H1, H2, H3 and $\mathrm{H} 4$ by using annual forecast accuracy, quarterly forecast accuracy and overall forecast accuracy, respectively. The coefficient estimate on Accounting is significantly positive in model 11 . For the effect of duality on forecast accuracy, we find that the coefficients on CFO_Duality and Mag_Duality are significantly positive in models 3, 5, 13 and 15 , which supports our $\mathrm{H} 3 \mathrm{~b}$ and $3 \mathrm{c}$, that also holding an additional senior role in a firm contributes to board secretaries' concentrated power and information advantage, with which they can produce more accurate estimates about future earnings. Furthermore, we report a significantly negative relation between Equityhold and Accuracy in all models, supporting $\mathrm{H} 4$.

We also examine whether and how board secretary characteristics affect the way in which management earnings forecasts are directionally biased, and we report our results in Table 8. Panels A, B and $\mathrm{C}$ show results for testing of $\mathrm{H} 1$, $\mathrm{H} 2, \mathrm{H} 3$ and $\mathrm{H} 4$ by using annual forecast optimism, quarterly forecast optimism and overall forecast optimism, respectively. The coefficient estimates on Board_Duality and Mag_Duality are significantly positive in models 9, 13 and 15. The results reveal that board secretaries who also serve as board members or non-accounting senior executives generally issue more optimistically biased quarterly earnings forecasts, which literally means that their forecasts tend to exceed actual earnings. The result suggests that board secretaries with higher hierarchical status within firms, as evidenced by their dual senior positions, overestimate firm profitability and issue more optimistic future earnings estimates. In addition, we document a significantly positive coefficient on EquityHold in all models, suggesting that board secretaries with stockholdings tend to issue optimistically biased forecasts. This could result from the selfserving tendency of board secretaries. ${ }^{8}$

\section{Regulatory Change}

Although the duties of board secretaries have been specified in the Guidance for the Articles of Listed Company since $1997,{ }^{9}$ they were not covered in Company Law until

\footnotetext{
${ }_{8 \mathrm{We}}$ explore the issue by examining the association between the change in equity holdings of board secretaries and management forecast optimism. We identify 105 (556) firm-years with changes in the equity holdings of board secretaries. The untabulated result shows that forecasts issued one year before board secretaries' stockholdings decrease (increase) are more (less) optimistically biased. This is in the line with our interpretation of the self-serving benefits.

${ }^{9}$ The the Guidance for the Articles of Listed Company was issued by China Securities Regulatory Commission in 1997. See: http://www. csrc.gov.cn/pub/shenzhen/xxfw/tzzsyd/ssgs/sszl/ssgsfz/200902/t2009 0226_95511.htm.
} 


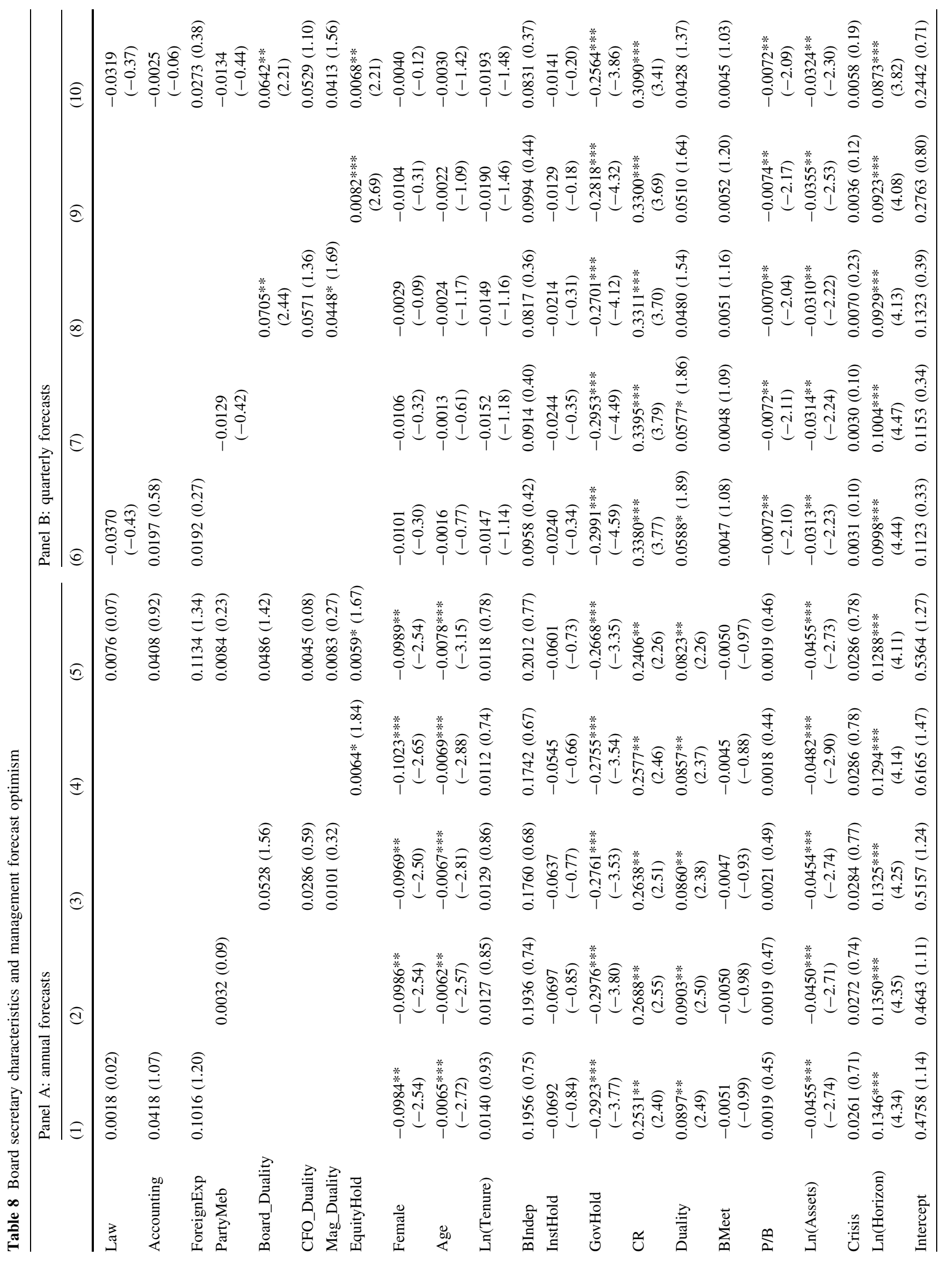




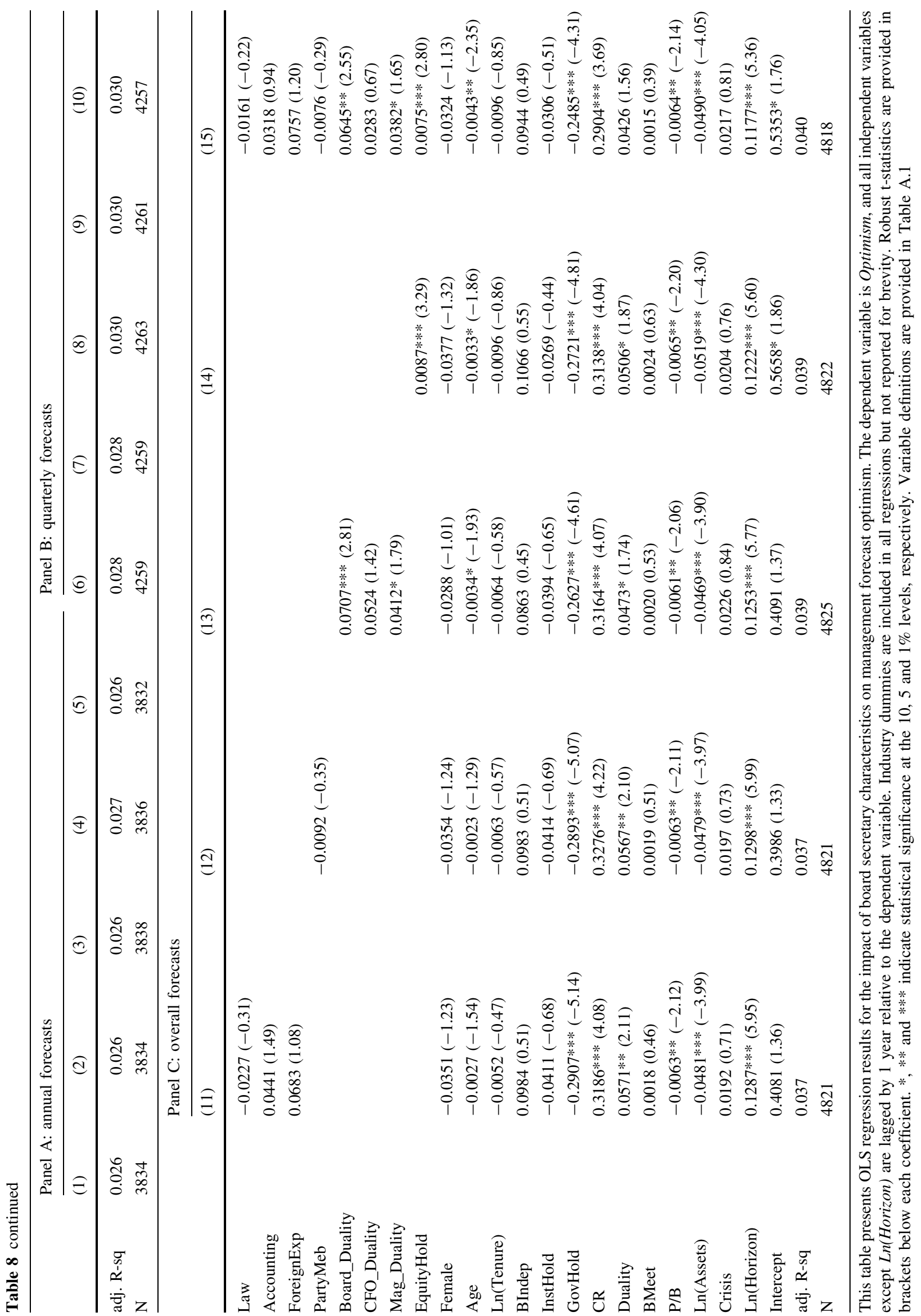




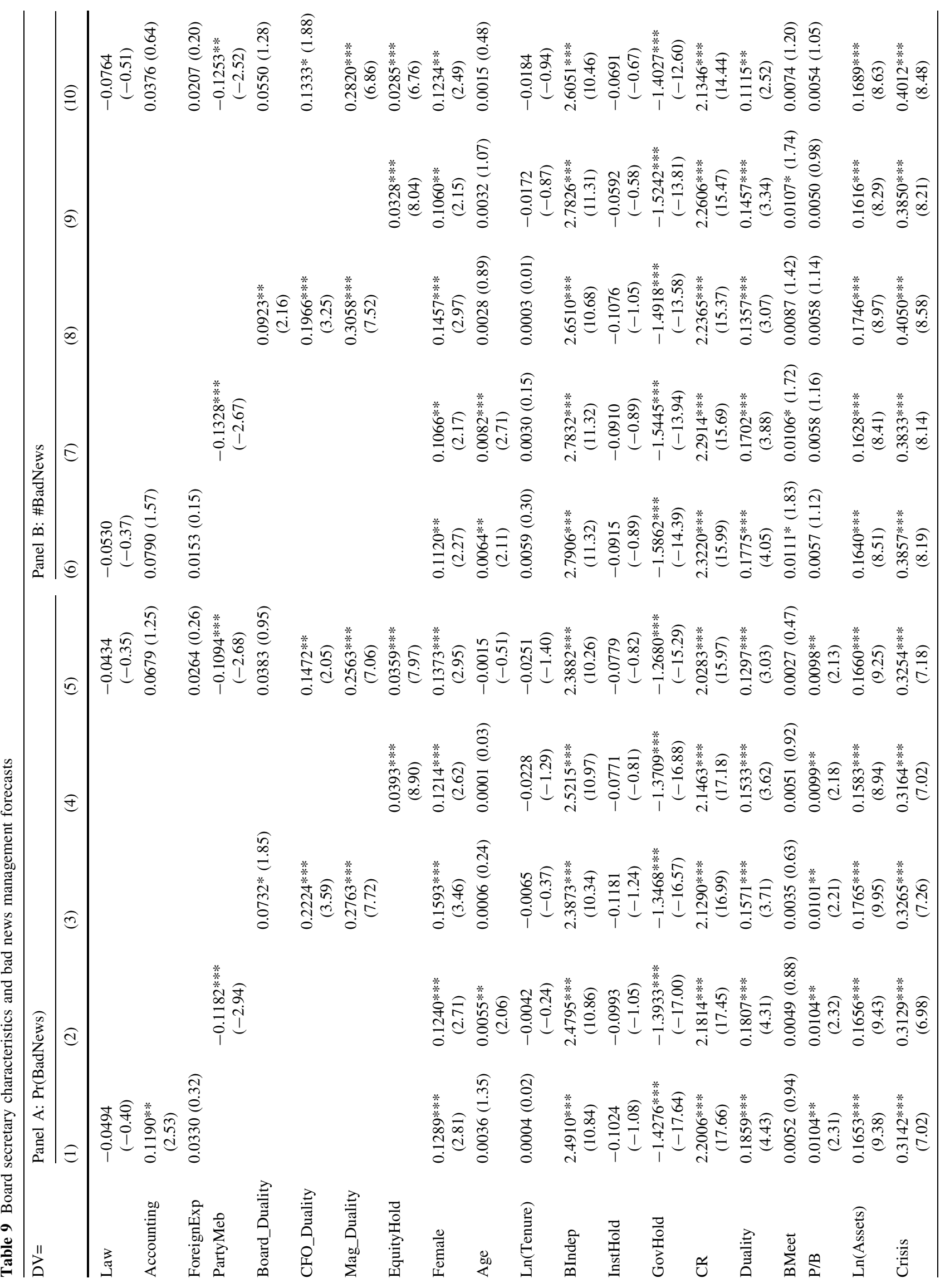




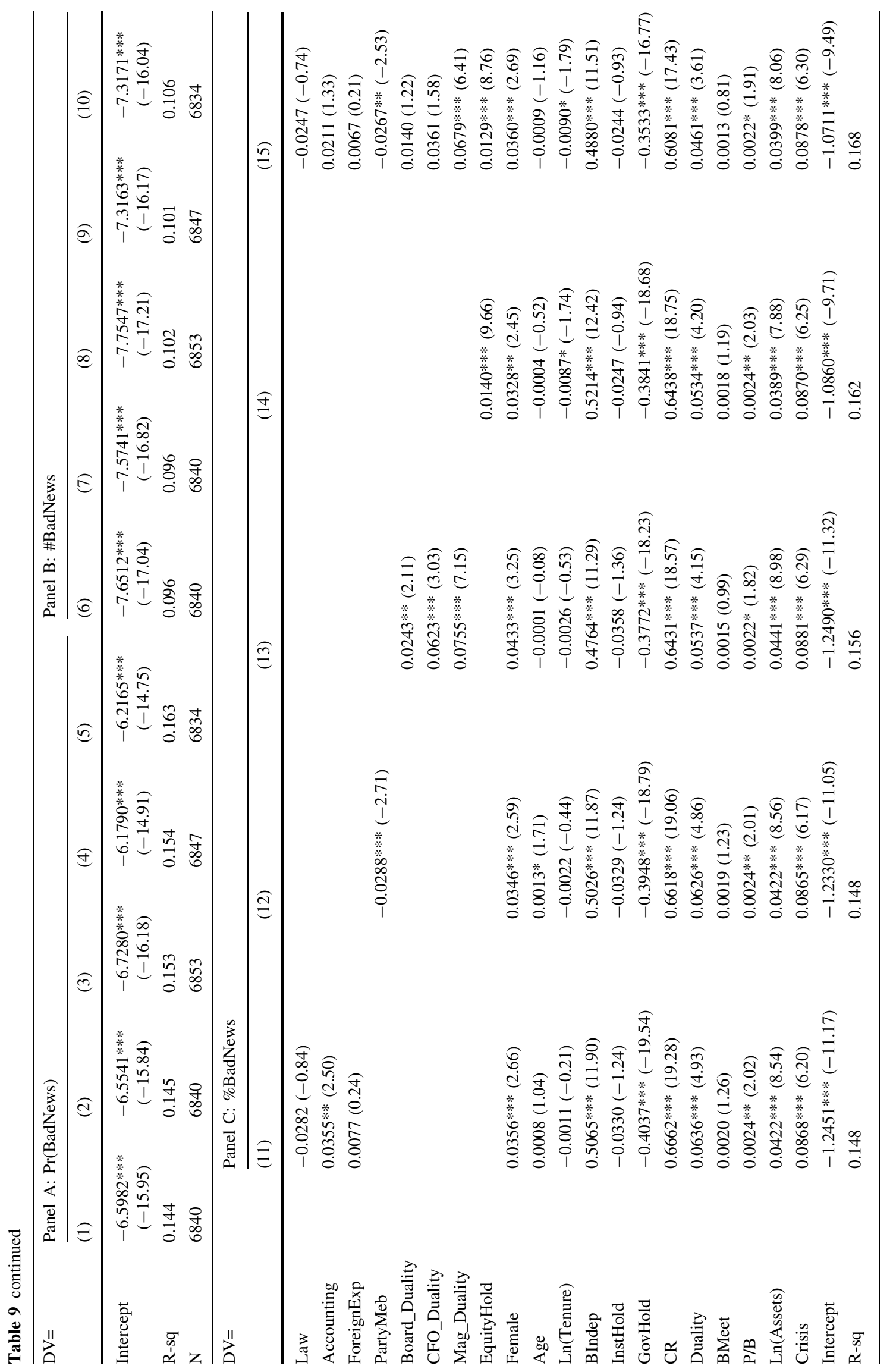




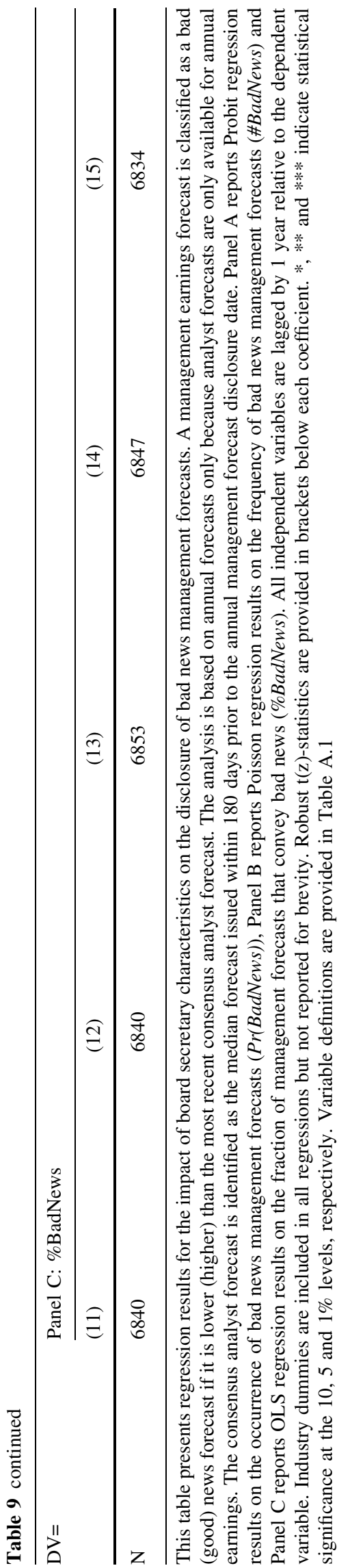

2005. In 2005, the revised Company Law regulated that a listed company must appoint a board secretary after 1 January 2006. We therefore examine whether the legislative change strengthens the impact of board secretary characteristics on management earnings forecasts. We construct Post a dummy variable equal to one if the year is 2006 or onward, and zero otherwise and interact each board secretary characteristics variable with Post. We regress forecast occurrence, forecast frequency, forecast precision, forecast accuracy, optimism and bad news forecast, respectively, on these variables and present the results in the unpublished appendix. The untabulated results indicate that the promulgation of the revised company law of 2005 has little effect on the impact of board secretaries on management earnings forecasts, presumably because the duties of board secretaries had been already clearly defined by China Securities Regulatory Commission (CSRC) in Guidance for the Articles of Listed Company promulgated in 1997.

\section{Additional Analyses}

\section{Board Secretary Characteristics and Bad News Versus Good News Management Forecasts}

Managers issue more bad news forecasts and downward guidance than other forecasts because this could help decrease their legal costs and reputational costs (Skinner 1994; Heflin et al. 2016). Since board secretaries by law have important legal and regulatory duties, they could face more litigation risks arising from irresponsible forecast disclosure. Thus, the characteristics of board secretaries should have an impact on bad news issuance. ${ }^{10}$

Following Heflin et al. (2016), we classify a management forecast as a bad (good) news forecast if it is lower (higher) than the most recent consensus analyst forecast, where the consensus forecast is identified as the median analyst forecast issued within 180 days prior to the management forecast disclosure date. Analyst forecast data are obtained from the CSMAR database. However, only annual analyst earnings forecast data are available in the database. Therefore, our analyses on bad news versus good news management forecasts rely on annual analyst earnings forecasts only. We study three different properties of bad news management forecasts, following Heflin et al. (2016): (1) $\operatorname{Pr}($ Bad news) is a dummy variable which is equal to one if the firm issues at least one bad news management earnings forecast in a given year, and zero otherwise; (2) \#Bad news is the number of bad news

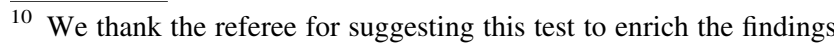
of our paper.
} 
management forecasts issued by a firm in a given year; and (3) \%Bad news is the fraction of management earnings forecasts issued by a firm in a given year that convey bad news. In line with Kross et al. (2011) and Heflin et al. (2016), our sample for bad news versus good news management forecast analysis includes firm-years both with and without management forecast issued. ${ }^{11}$

Table 9 presents the regression analysis results for the impact of board secretary characteristics on bad news and downward guidance. Panels A, B and C report Probit regression results on the occurrence of bad news management forecasts, Poisson regression results on the frequency of bad news management forecasts, and OLS regression results on the fraction of bad news management forecasts, respectively. The coefficient of Accounting is significantly positive in models 1 and 11, which suggests that board secretaries with accounting expertise are more likely to issue bad news and downward guidance and issue a higher fraction of bad news forecasts. The coefficient estimate on PartyMeb is negatively significant in all models. The results suggest that political connections decrease board secretaries' willingness to issue bad news and downward guidance forecast in terms of occurrence, frequency and fraction. The coefficients of Board_Duality, CFO_Duality, Mag_Duality and EquityHold are significantly positive, offering further evidence that board secretaries with dual roles and equity holdings are associated with more frequent issuance of bad news and downward guidance management forecasts. Overall, board secretaries with professional expertise, dual roles and equity holdings are more likely to issue bad news and downward guidance. Their willingness to issue bad news and downward guidance decreases when they have political connections.

\section{Management Earnings Forecasts and Board Secretary Pay}

The literature reveals that management earnings forecasts are used by investors to evaluate managers' abilities to adapt future production plans in response to foreseeable changes in the business environment (Trueman 1986; Baik et al. 2011; Yang 2012). Lee et al. (2012) further show that management earnings forecast errors increase the likelihood of poorly performing CEOs being replaced. These studies generally suggest that management earnings forecasts provide an important signal of managerial ability. Thus, in this paper we argue that firms use management earnings forecasts to evaluate board secretaries' performance, because they have a duty to reduce information asymmetry between corporate insiders and outside

\footnotetext{
11 When there is no management forecast issuance in a given firmyear, $\operatorname{Pr}($ Bad news), \#Bad news and \%Bad news are set as zero.
}

investors by ensuring full and accurate forecast disclosure. Since investors may favourably evaluate firms with frequent forecast issuance and high forecast precision and accuracy, these firms that benefit from improved forecast disclosure are likely to reward their board secretaries with higher compensation. Therefore, we predict that board secretaries' pay is positively related to the occurrence, frequency, precision and accuracy of management forecasts. To verify our prediction, we estimate regressions where the dependent variable is $\operatorname{Ln}($ Pay), calculated as the natural logarithm of the sum of a board secretary's salary and bonus. The independent variables are lagged by 1 year relative to the dependent variable.

Table 10 presents the regression results for management earnings forecasts and board secretary pay. ${ }^{12}$ Panel A reports the results by using the OLS estimator. In models 1-6, we regress board secretary Pay on each of the forecast property variables, respectively, and then in model 7 we include all properties of management forecasts if there is at least one forecast issuance, i.e., the value of Occurrence is one. We report in model 1 that the coefficient on Occurrence is significantly positive at the $1 \%$ level, implying board secretaries that issue forecasts receive higher compensation than secretaries without forecast issuance. In models 2-6, which consider the situation where at least one forecast is disclosed by board secretaries in a given year, we find the coefficients on Frequency, Precision, Accuracy and \%BadNews consistently significantly positive, consistent with the argument that pay is significantly higher for board secretaries that issue high-quality forecasts. The coefficient of Optimism is significantly negative, which suggests that board secretaries who issue less optimistically biased forecasts receive higher pay. The results also reveal the link between board secretary characteristics and pay. For example, board secretaries with foreign experience, dual roles and stock holdings receive more compensation, on average, while pay is significantly lower for secretaries with Party membership.

One concern is the potential reverse causality and omitted variables issue for the impact of management forecasts on board secretary pay. One can definitely expect that higher compensation and job retention have an impact on accuracy. ${ }^{13}$ First, we address this concern by considering the lagged independent variables in Panel A of Table 10. Second, we further address the potential reverse causality and omitted variables issues by using a dynamic

\footnotetext{
12 Board secretaries' pay and replacement decisions should be made based on the overall board secretaries' forecast quality. Thus, we use overall management forecast sample, without dividing it into the annual and quarterly forecasts. The impact of quarterly and annual management forecasts on board secretary pay is provided in our unpublished appendix.

${ }^{13}$ We thank the referee for pointing this out.
} 


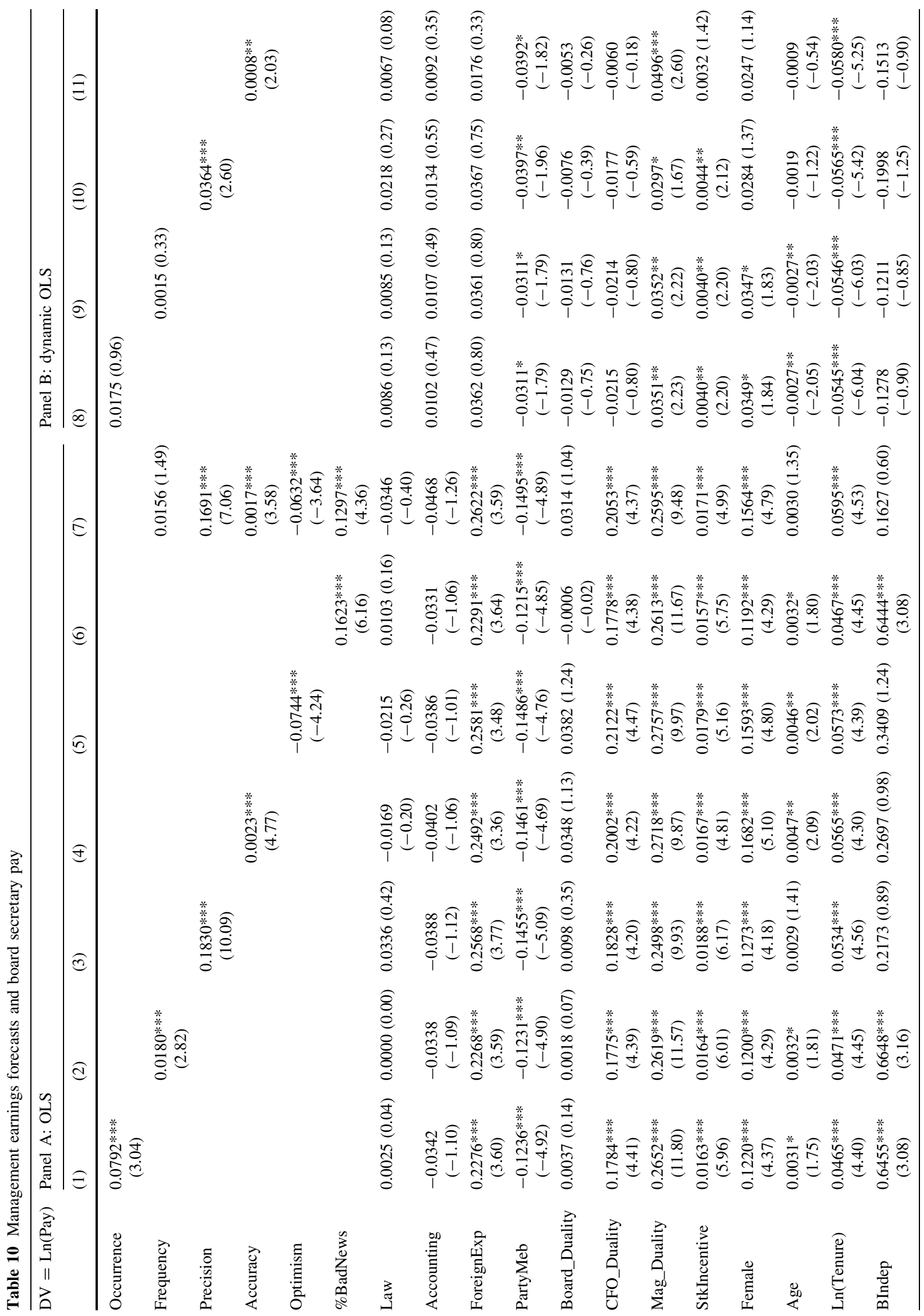




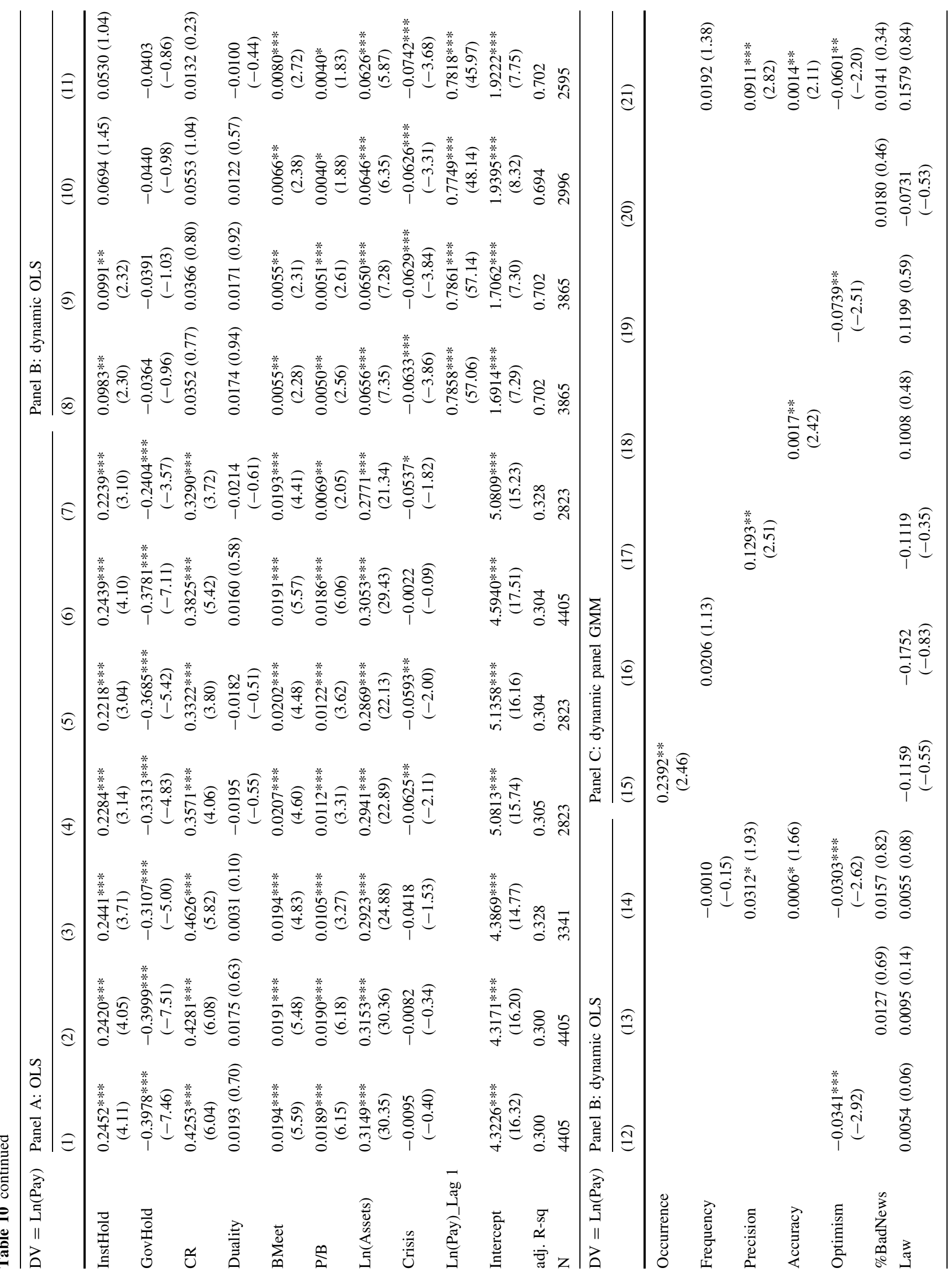




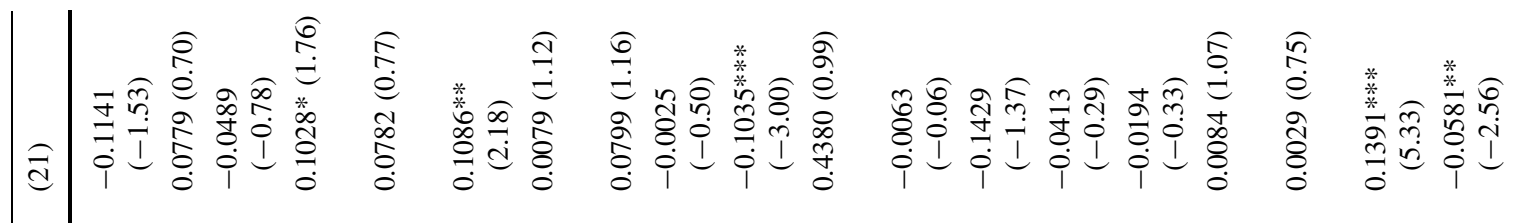

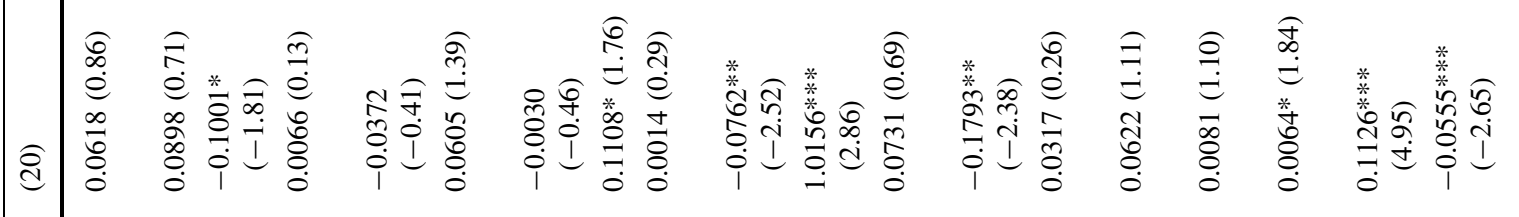

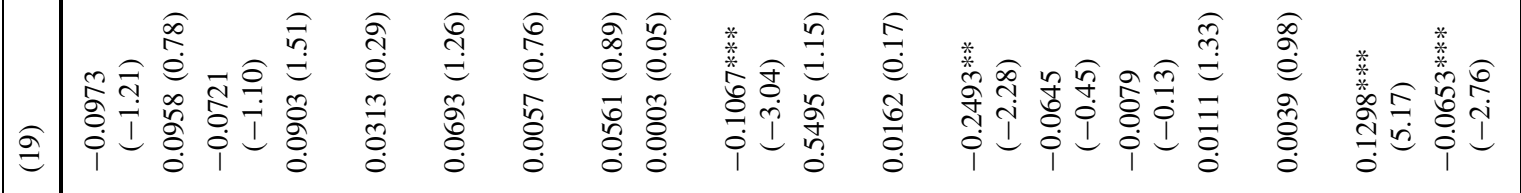

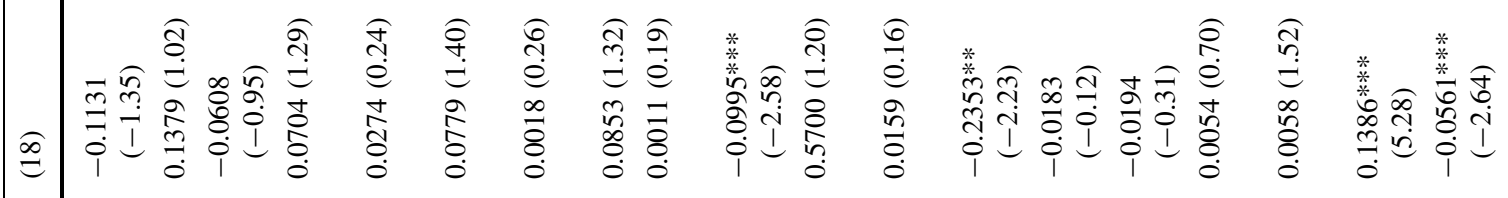

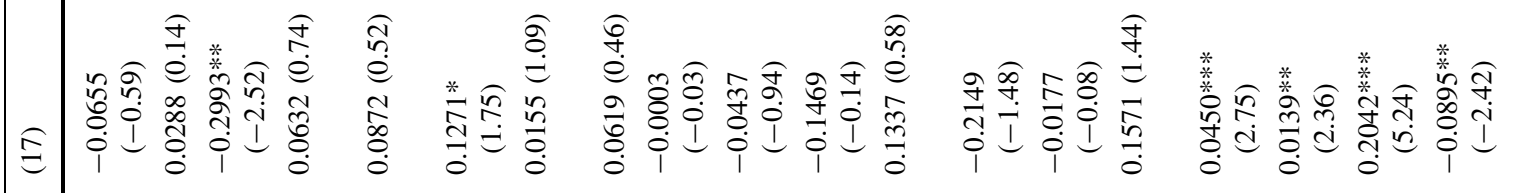

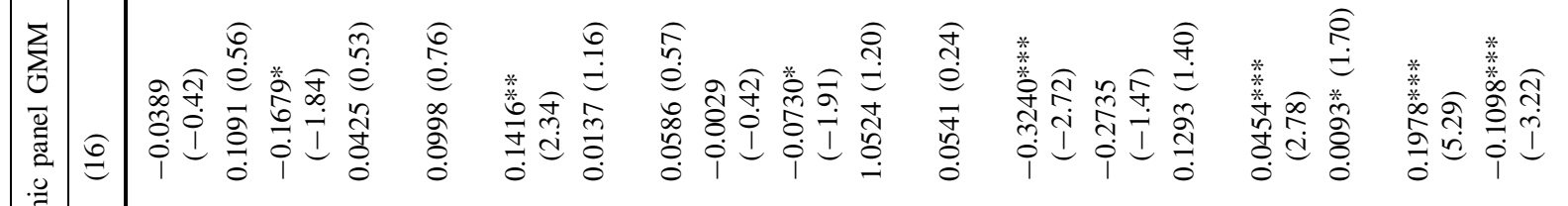

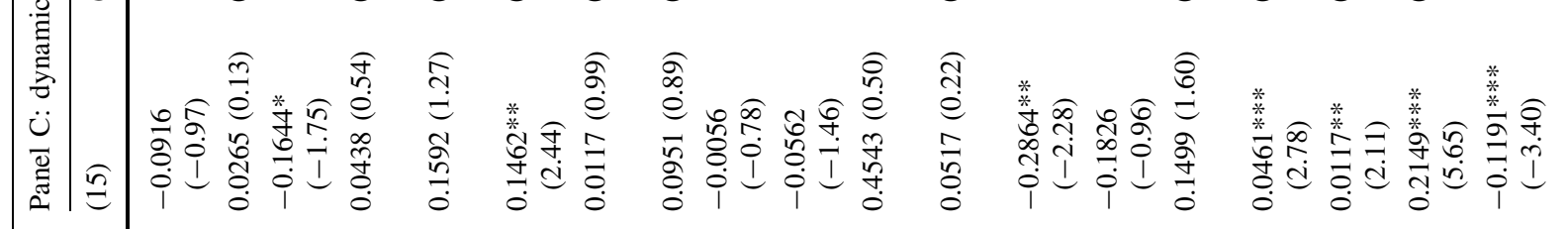

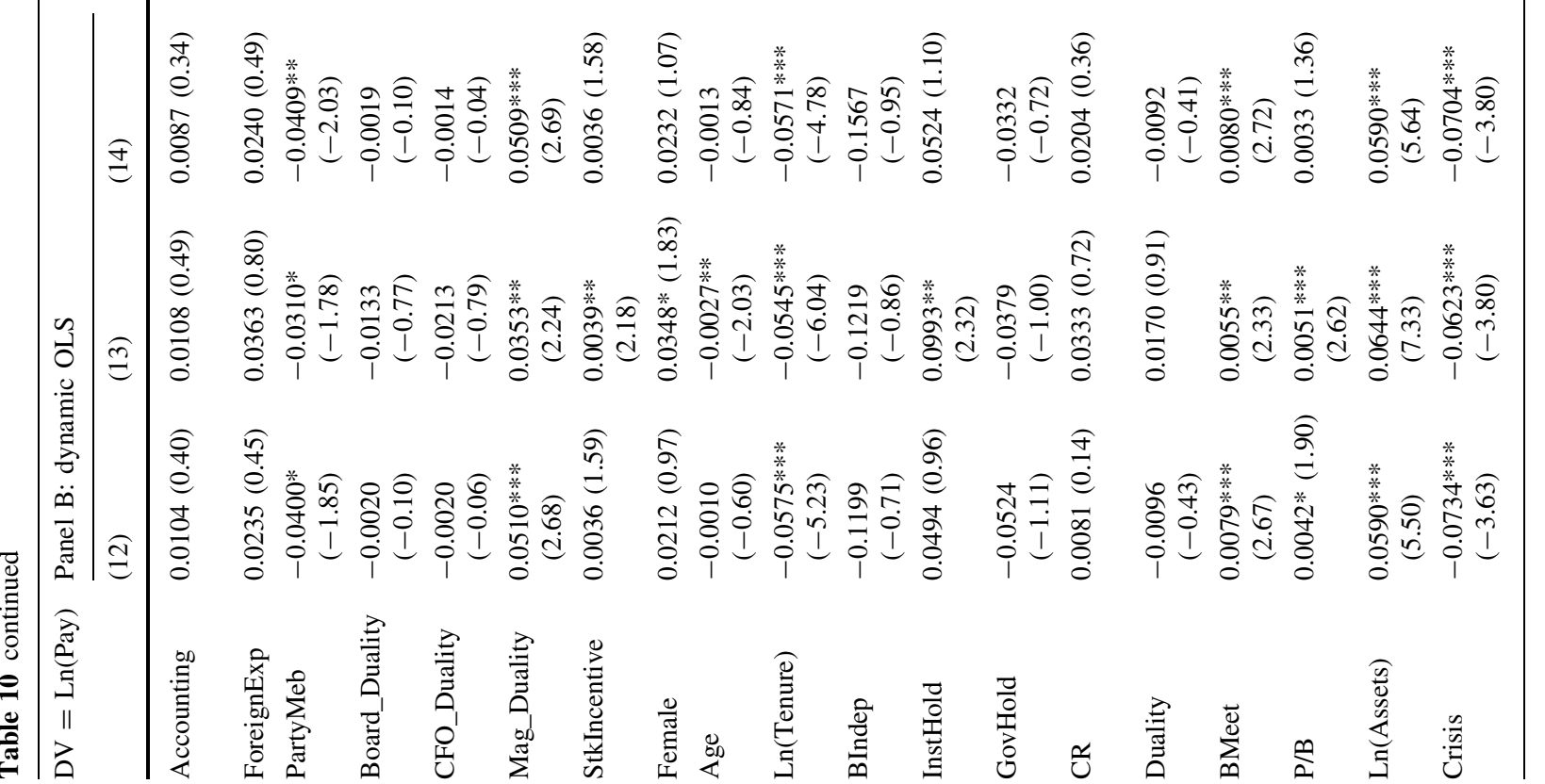




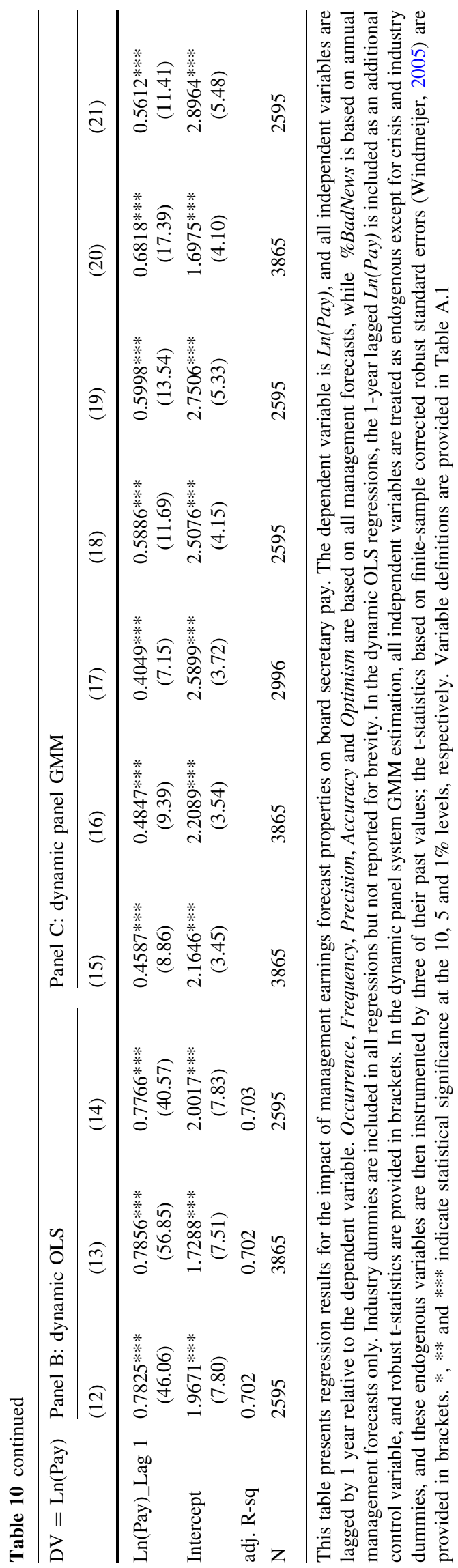

model and dynamic panel GMM estimator, following Adams and Ferreira (2009) and Dezsö and Ross (2012). The results for management earnings forecasts and board secretary pay using dynamic OLS and dynamic panel GMM estimator appear in Panels B and C of Table 10, respectively. The results are consistent with those from using the OLS estimator, which suggests that our results are not subject to reverse causality and omitted variable issues.

\section{Management Earnings Forecasts and Board Secretary Turnover}

Consistent with our previous findings about the effects of management forecasts on board secretaries' pay, we expect that firms also employ management earnings forecasts to evaluate board secretaries' performance and abilities when making replacement decisions. To examine the effects of management forecasts on board secretary turnover, we estimate regressions where the dependent variable is Turnover, with a value set to one if a board secretary is replaced in a given firm-year, and zero otherwise. The independent variables are lagged by 1 year relative to the dependent variable.

In Table 11, we report the regression results for board secretary turnover. Panels A, B and C report the results by using a Probit model, dynamic linear probability model and dynamic panel GMM model, respectively. In Panel A, the coefficients of Occurrence and Frequency are significantly positive, indicating that more frequent forecasts increase the likelihood of board secretaries being replaced. In addition, the coefficient on Precision and Accuracy is significantly negative in models 4 and 6 , suggesting that the more precise and accurate forecasts are the less likely it is that board secretaries will be replaced. Our result also provides additional support for the findings of Lee et al. (2012), who suggest that management forecast errors increase the probability of managerial turnover. Furthermore, the regression results show that board secretaries with a dual board role have a high tendency to be replaced. This result suggests that board secretaries with a second board role tend to keep the senior title and give up the board secretary role. ${ }^{14}$ In addition, we use a dynamic linear probability model and dynamic panel GMM model to address the potential reverse causality issue and show the

\footnotetext{
${ }^{14}$ Our sample contains a total of 944 board secretary turnover observations, among which 322 board secretaries have a second board of directors role prior to leaving the board secretary position, and 166 (52\%) of these former board secretaries continue to hold their board director position. This result supports our argument that dual-role directors tend to keep the relatively important position (i.e., the director position on the board) and abandon the insignificant board secretary role.
} 
results in Panels B and C, respectively. The results are broadly consistent.

As a robustness test, we create a new sample that includes only the firm-years in which corporate boards are routinely replaced. Since board secretaries are appointed by boards of directors and report directly to the boards, they are likely to be replaced during routine board turnover. We use the restricted sample to re-estimate the Probit regressions, and the results still hold, with the likelihood of board secretary turnover being negatively related to management forecast accuracy, which supports our finding that board secretaries are less likely to be replaced if they produce making high-quality forecasts. This result further indicates that newly appointed directors are more likely to retain former board secretaries if the secretaries performed well in previous years.

\section{Board Secretary Characteristics and Firm-level Outcomes}

In addition to enhancing forecast disclosure, board secretaries may also impact firm outcomes because they are top management team members, with a duty to ensure that corporate decisions comply with laws and regulations. Therefore, to further explore the role of board secretaries in firms, we test the impact of board secretary characteristics on financial report quality, lawsuits, corporate social responsibility, firm policy, earnings quality and firm performance using the OLS estimation method. To measure financial report quality, we employ modified auditor opinion, which is a dummy variable equal to one if a modified auditor opinion is issued to a firm, and zero otherwise. Lawsuits is proxied by sue, which is a dummy variable equal to one if there is a lawsuit against a firm, and zero otherwise. Corporate social responsibility is measured by donation and CSR disclosure. Donation is the natural logarithm of social donations (in Chinese RMB). CSR disclose is a dummy variable equal to one if a firm discloses its corporate social responsibility in annual reports, and zero otherwise. For firm policy, we use capital expenditure, which is the ratio of capital expenditure to cash flow, where cash flow is calculated as earnings before extraordinary terms plus depreciation. Earnings quality is measured by earnings opacity, which is the absolute value of discretionary accruals calculated based on the Dechow and Dichev (2002) model. Firm performance is measured by return on assets (ROA), return on sales (ROS) and Tobin's Q.

Table 12 presents the regression analyses results for the impact of board secretaries on firm outcome. ${ }^{15}$ In model 1, the result shows that board secretaries with a dual director

$\overline{15}$ All dependent variables in Table 12 are led 1-year. role positively increase the incidence of modified auditor opinions and that board secretaries with a dual CFO role and equity holdings decrease the possibility of modified auditor opinions. In model 2 , the result indicates that firms are less likely to be sued in the present time if board secretaries formerly received equity holdings. In model 3 , the coefficients of Accounting and EquityHoldings are significantly positive, suggesting that board secretaries with accounting expertise and equity holdings have a positive effect on corporate donations. Model 4 shows that firms are less likely to disclose CSR in annual reports when board secretaries are politically connected. In model 5 , the result indicates that the foreign experience and party membership of board secretaries decrease the ratio of capital expenditure to cash flow, while their equity holdings increase the ratio. In model 6 , the result suggests that firms are associated with higher discretionary accruals when board secretaries have dual director roles, non-CFO dual senior roles and lower equity holding. Models 7-9 generally suggest that board secretaries have a positive impact on firm performance, including ROA, ROS and Tobin's Q, if they have equity holdings. Overall, the results suggest that the characteristics of board secretaries have a positive effect on firm outcomes, especially when board secretaries have equity holdings. These equity holdings could help firms to improve corporate governance, business ethics, investment and firm performance.

\section{Conclusion}

This study investigates board secretaries' role in management earnings forecasts of Chinese listed firms. Considerable research has been conducted to examine the influence of CEOs, CFOs and General Counsels on management forecast disclosure, but that of board secretary, an important senior position responsible for disclosing corporate information to regulators, investors and financial analysts has been largely ignored by previous research. Given their particular role in information disclosure, we expect that board secretaries' performance in forecast issuance has significant implications for information transmission between inside managers and outside investors, which consequently affects the quality of information employed by investors in their decision making. Thus, we investigate the effects of professional ability, political connections, dual senior titles and equity holdings of board secretaries on the occurrence, frequency, precision and accuracy of management earnings forecasts. Our results generally suggest that the quality of management earnings forecasts is positively associated with the legal expertise, accounting expertise, foreign experience, dual senior titles and stock 


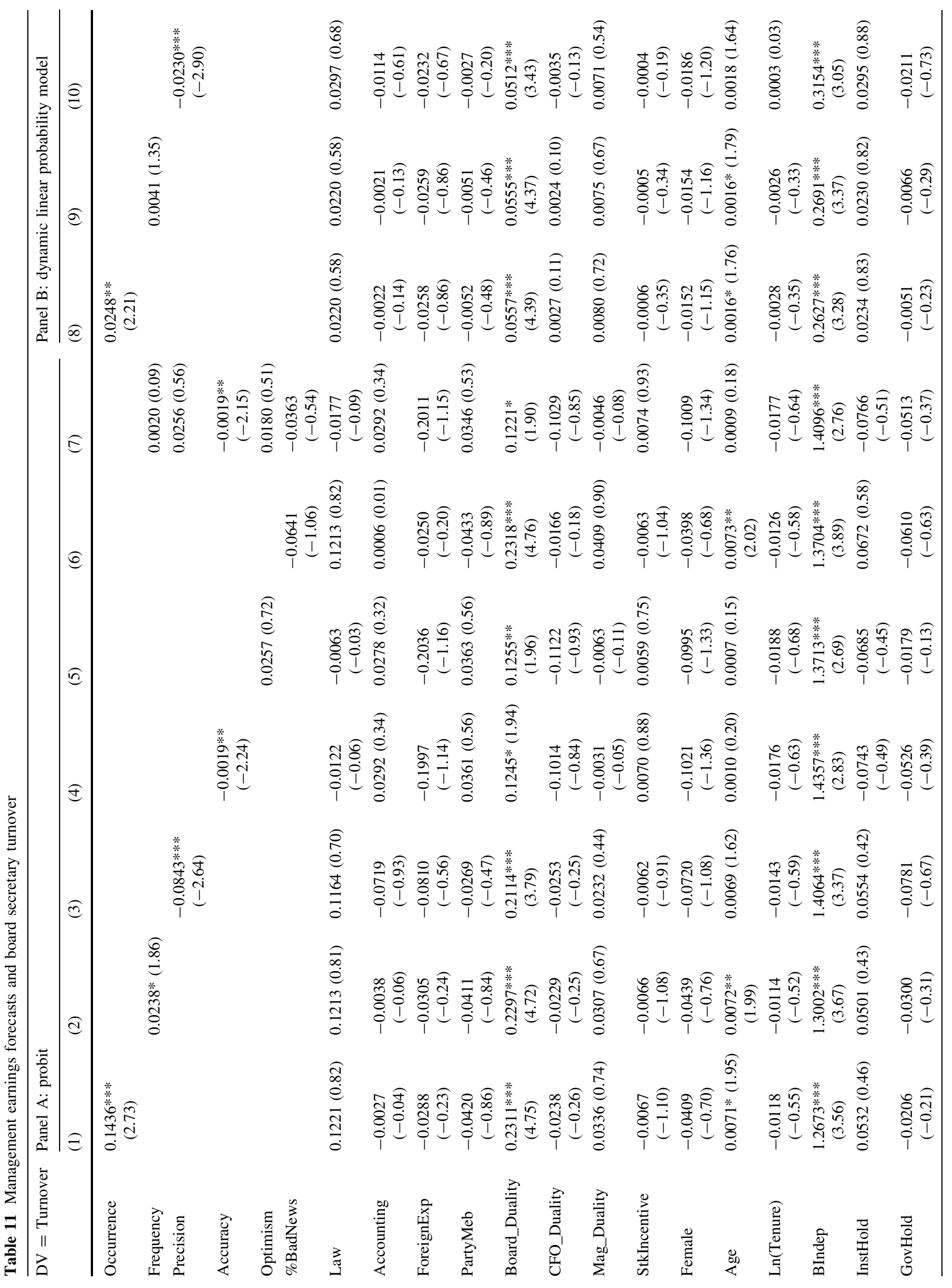




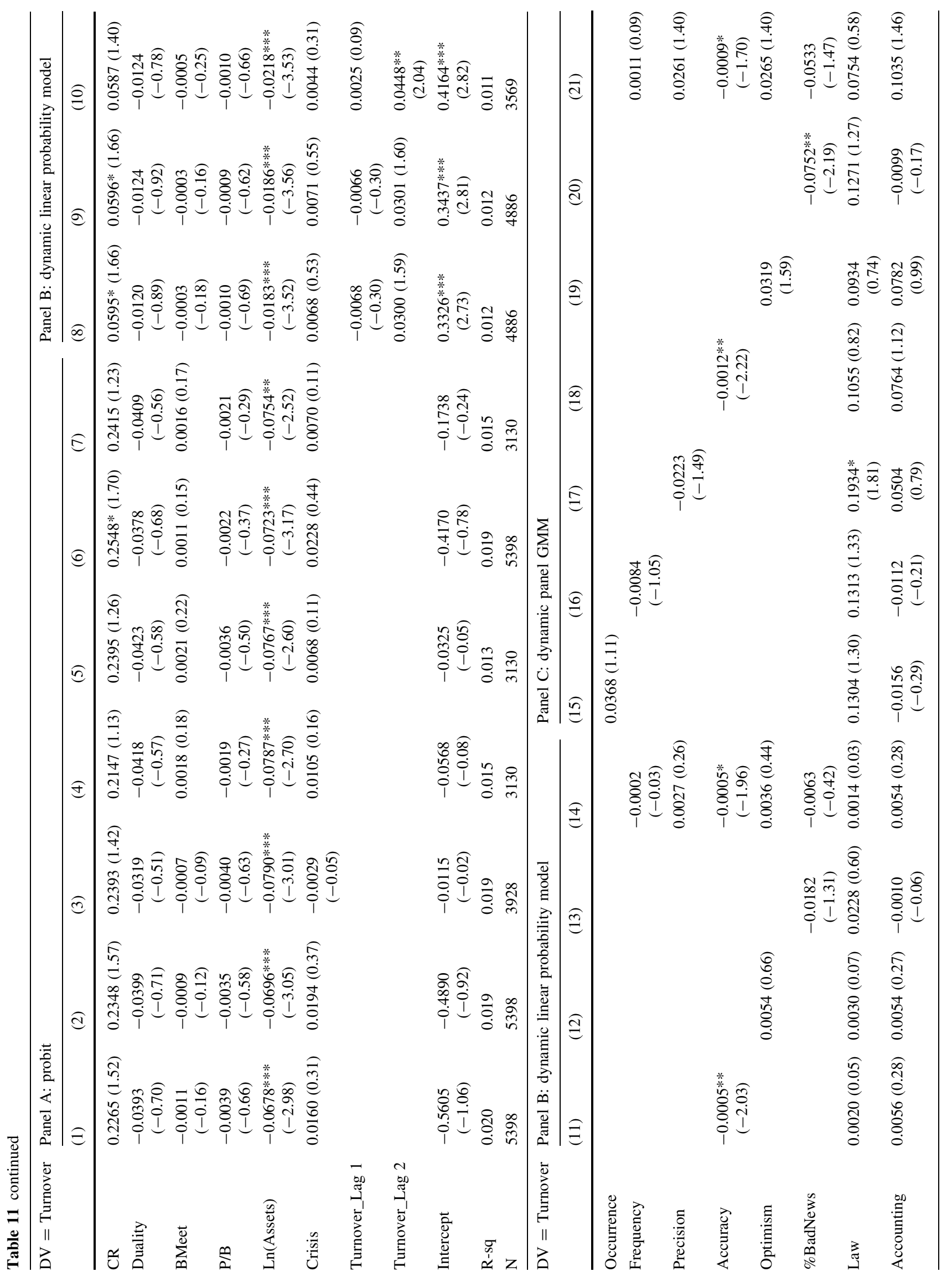




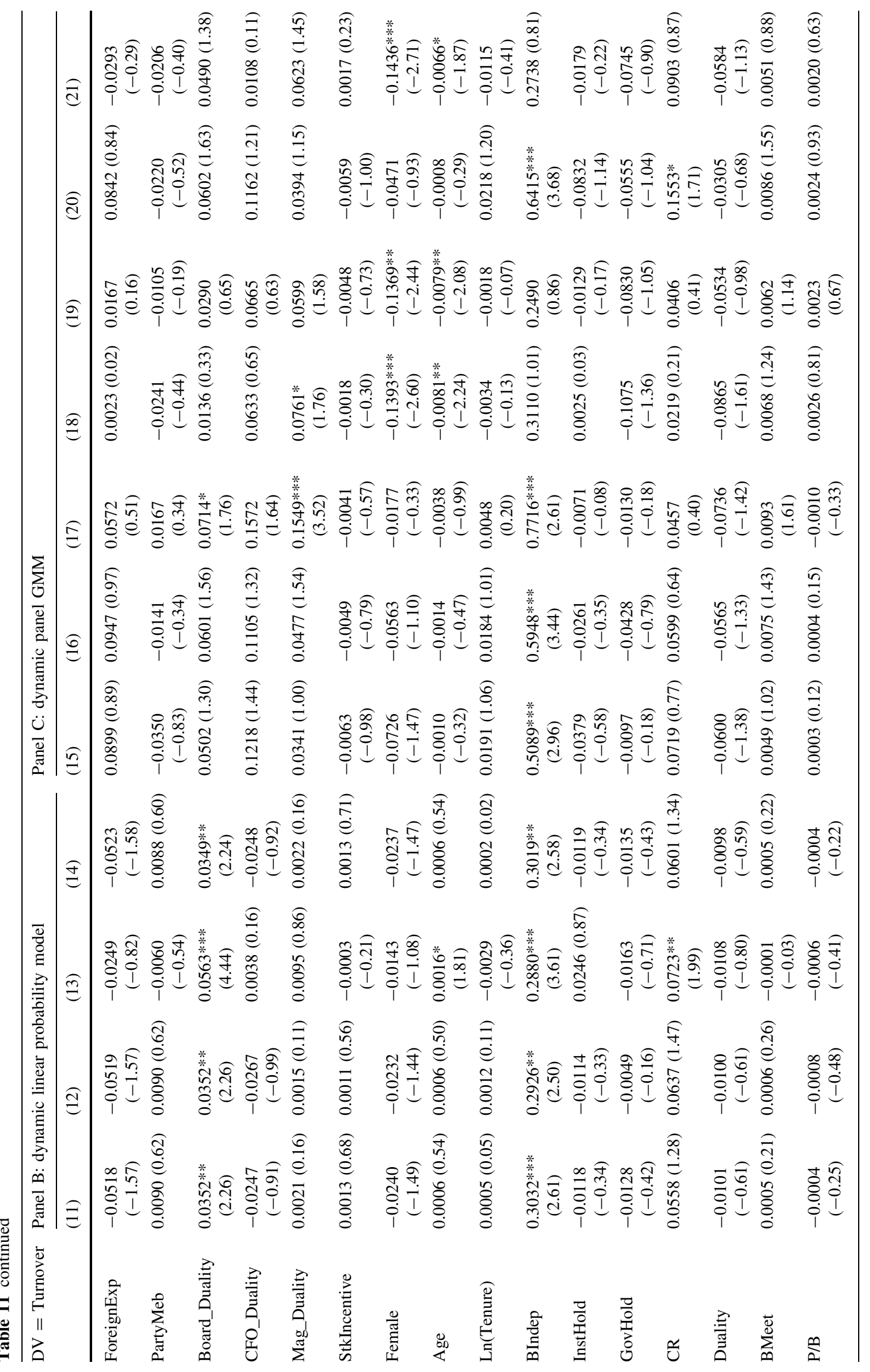




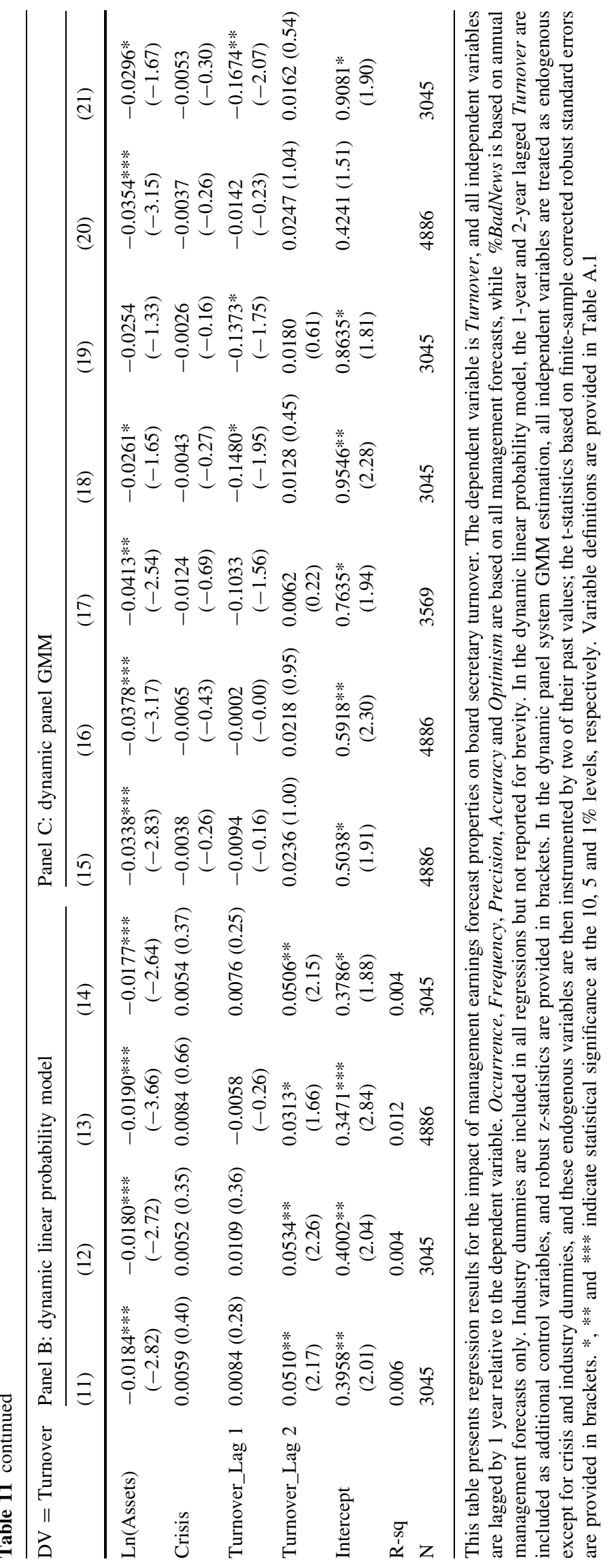




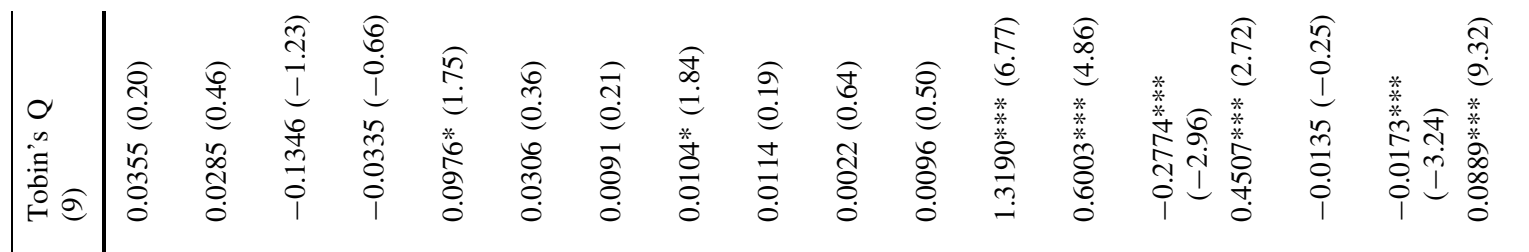

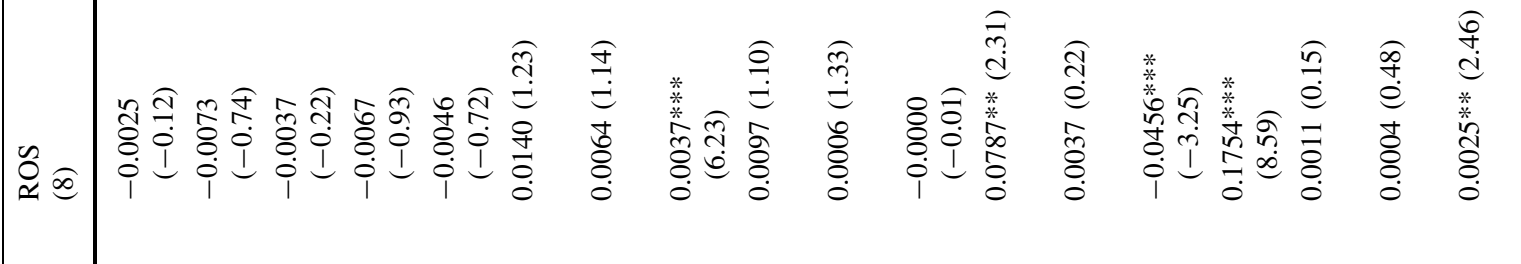

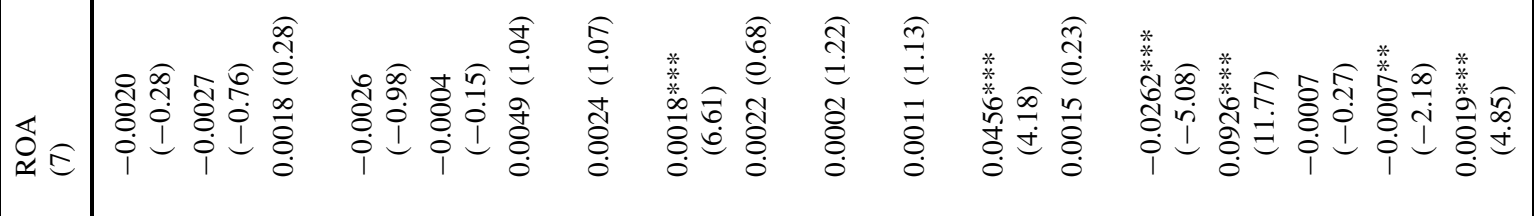

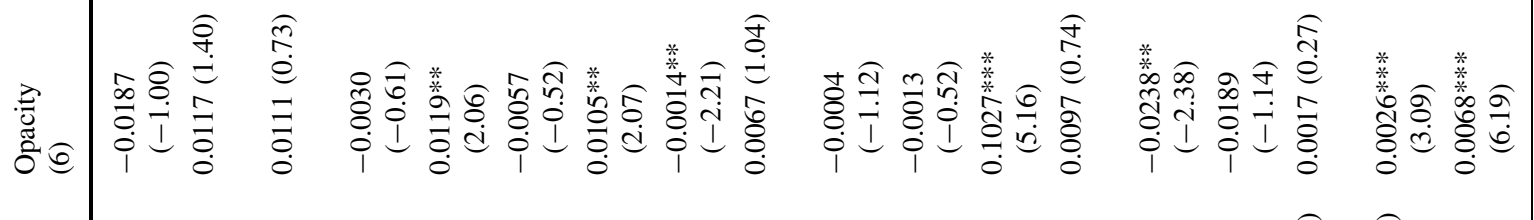

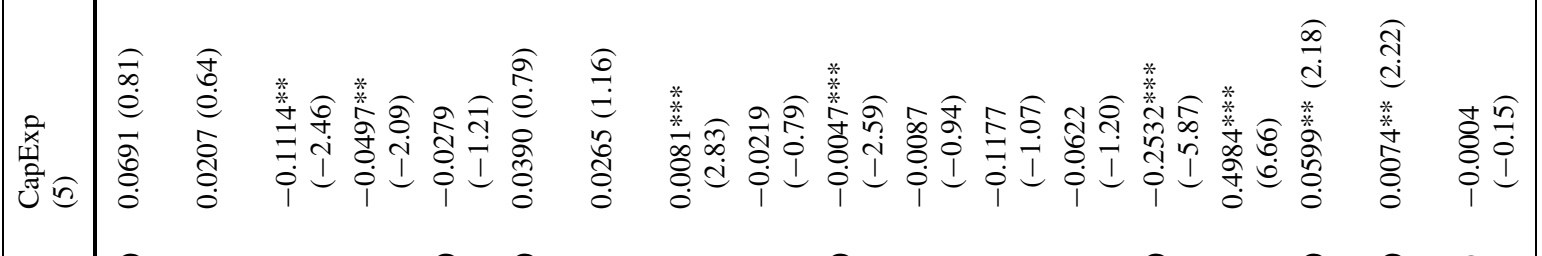

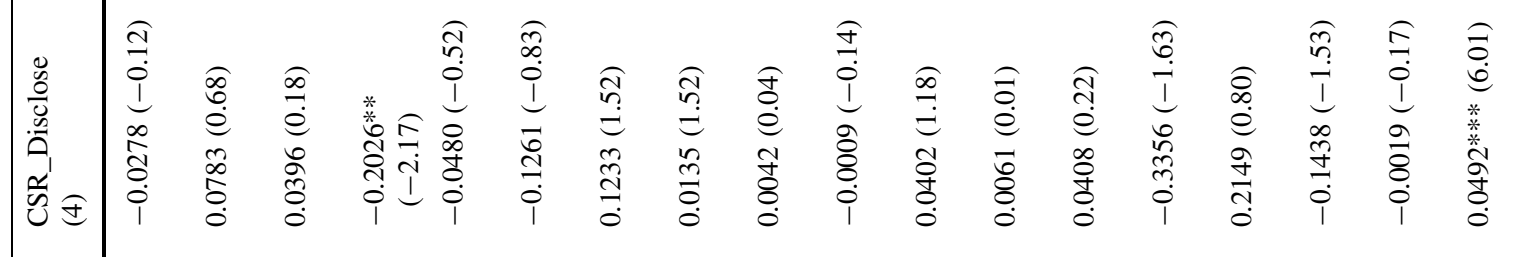

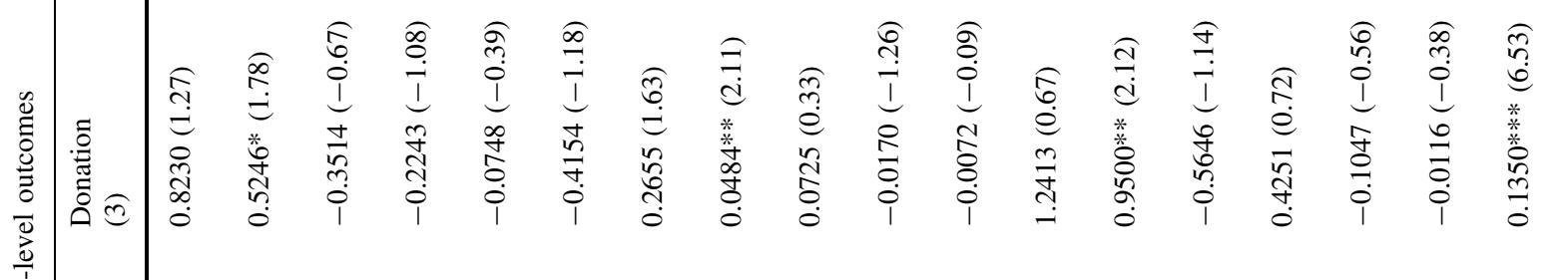

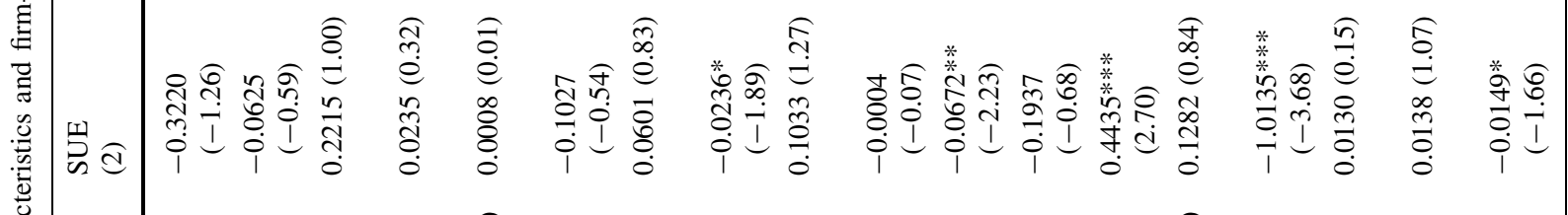

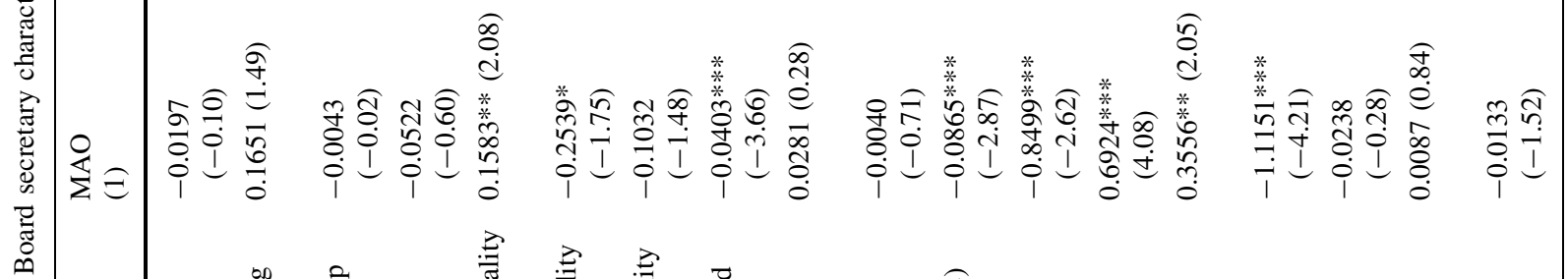

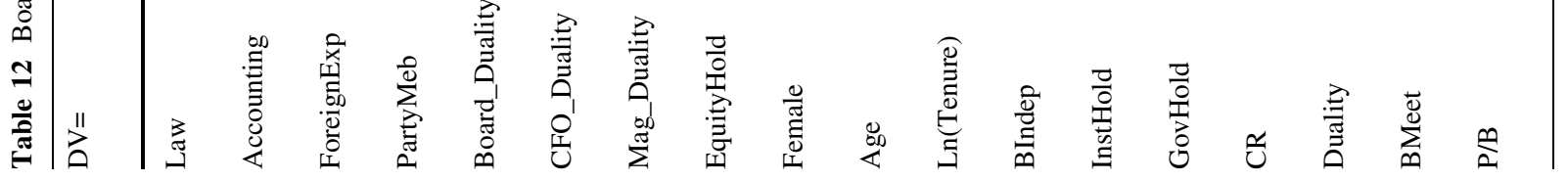




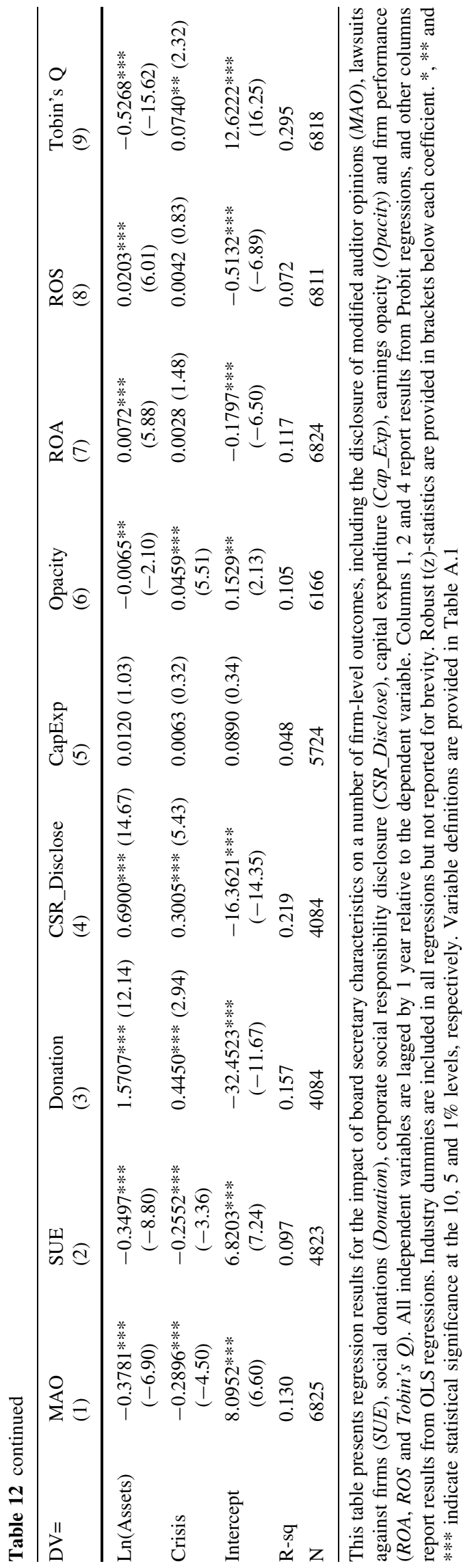

ownership of board secretaries and negatively related to their membership in the Chinese Communist Party.

In addition, board secretaries with accounting expertise, dual senior roles and equity holdings issue more bad news forecasts and downward guidance than other forecasts. We also show that firms make compensation and replacement decisions for board secretaries according to their performance in disclosing forecast and that board secretaries, on average, receive higher compensation and have a lower likelihood of being replaced when they deliver higher quality forecasts to the public. Our additional analyses provide further evidence on the significant role of board secretaries in corporate governance, business ethics, investment and firm performance. Overall, our study provides the first evidence that board secretaries play an important role in management earnings forecasts, which adds to the literature on forecast disclosure, corporate governance and business ethics. We encourage future research on board secretaries to explore their other duties, such as investor relationship management, coordinating board meetings and legal compliance.

Acknowledgements We are grateful for helpful comments from the editor, two anonymous referees, Chen Wang, Lucy Liu and participants at the FMA Annual Meeting at Nashville and seminar participants at the University of Edinburgh.

\section{Compliance with Ethical Standards}

Conflict of interest All authors declare that they have no conflict of interest.

Ethical approval This article does not contain any studies with human participants performed by any of the authors.

Open Access This article is distributed under the terms of the Creative Commons Attribution 4.0 International License (http:// creativecommons.org/licenses/by/4.0/), which permits unrestricted use, distribution, and reproduction in any medium, provided you give appropriate credit to the original author(s) and the source, provide a link to the Creative Commons license, and indicate if changes were made.

\section{References}

Aabo, T., Fraser, J. R., \& Simkins, B. J. (2005). The rise and evolution of the chief risk officer: enterprise risk management at Hydro One. Journal of Applied Corporate Finance, 17(3), $62-75$.

Adams, R. B., \& Ferreira, D. (2009). Women in the boardroom and their impact on governance and performance. Journal of Financial Economics, 94, 291-309.

Ajinkya, B., Bhojraj, S., \& Sengupta, P. (2005). The association between outside directors, institutional investors and the properties of management earnings forecasts. Journal of Accounting Research, 43(3), 343-376.

Anilowski, C., Feng, M., \& Skinner, D. J. (2007). Does earnings guidance affect market returns? The nature and information 
content of aggregate earnings guidance. Journal of Accounting and Economics, 44, 36-63.

Baginski, S. P., \& Hassell, J. M. (1997). Determinants of management forecast precision. The Accounting Review, 47, 303-312.

Baik, B. O. K., Farber, D. B., \& Lee, S. S. (2011). CEO ability and management earnings forecasts. Contemporary Accounting Research, 28(5), 1645-1668.

Bamber, L. S., \& Cheon, Y. S. (1998). Discretionary management earnings forecast disclosures: Antecedents and outcomes associated with forecast venue and forecast specificity choices. Journal of Accounting Research, 36(2), 167-190.

Bamber, L. S., Jiang, J., \& Wang, I. Y. (2010). What's my style? The influence of top managers on voluntary corporate financial disclosure. The Accounting Review, 85(4), 1131-1162.

Barua, A., Davidson, L. F., Rama, D. V., \& Thiruvadi, S. (2010). CFO gender and accruals quality. Accounting Horizons, 24(1), 25-39.

Beck, M. J., \& Mauldin, E. G. (2014). Who's really in charge? Audit committee versus CFO power and audit fees. The Accounting Review, 89(6), 2057-2085.

Bergstresser, D., \& Philippon, T. (2006). CEO incentives and earnings management. Journal of Financial Economics, 80(3), 511-529.

Bird, R. C., Borochin, P. A., \& Knopf, J. D. (2015). The role of the chief legal officer in corporate governance. Journal of Corporate Finance, 34, 1-22.

Boyd, B. K. (1990). Corporate linkages and organizational environment: A test of the resource dependence model. Strategic Management Journal, 11(6), 419-430.

Boyd, B. K. (1995). CEO duality and firm performance: A contingency model. Strategic Management Journal, 16(4), 301-312.

Brochet, F., Faurel, L., \& McVay, S. (2011). Manager-specific effects on earnings guidance: An analysis of top executive turnovers. Journal of Accounting Research, 49(5), 1123-1162.

Burns, N., \& Kedia, S. (2006). The impact of performance-based compensation on misreporting. Journal of Financial Economics, 79(1), 35-67.

Cao, J., Pan, X., \& Qian, M. (2011). Political connection and managerial entrenchment: Evidence from CEO turnovers in China. Available at SSRN 1786103.

Carpenter, M. A., Sanders, W. G., \& Gregersen, H. B. (2001). Bundling human capital with organizational context: The impact of international assignment experience on multinational firm performance and CEO pay. Academy of Management Journal, 44(3), 493-511.

Cassell, C. A., Huang, S. X., \& Sanchez, J. M. (2013). Forecasting without consequence? Evidence on the properties of retiring CEOs' forecasts of future earnings. The Accounting Review, 88(6), 1909-1937.

Chen, J., Cumming, D., Hou, W., \& Lee, E. (2016). CEO accountability for corporate fraud: Evidence from the split share structure reform in China. Journal of Business Ethics, 138, 787-806.

Cheng, Q., \& Lo, K. (2006). Insider trading and voluntary disclosures. Journal of Accounting Research, 44, 815-848.

Cheng, Q., Luo, T., \& Yue, H. (2013). Managerial incentives and management forecast precision. The Accounting Review, 88(5), $1575-1602$.

Cumming, D. J., Duan, T., Hou, W., \& Rees, B. (2016). Do returnee CEOs transfer institutions? Evidence from Newly Public Chinese Entrepreneurial Firms. Available at SSRN 2780680.

Cumming, D., Hou, W., \& Lee, E. (2016b). Business ethics and finance in greater China: Synthesis and future directions in sustainability, CSR, and fraud. Journal of Business Ethics, 138, $1-26$.
Datta, S., Iskandar-Datta, M. A. I., \& Raman, K. (2005). Managerial stock ownership and the maturity structure of corporate debt. Journal of Finance, 60(5), 2333-2350.

Dechow, P. M., \& Dichev, I. D. (2002). The quality of accruals and earnings: The role of accrual estimation errors. The Accounting Review, 77, 35-59.

Dezsö, C. L., \& Ross, D. G. (2012). Does female representation in top management improve firm performance? A panel data investigation. Strategic Management Journal, 33, 1072-1089.

Donaldson, L., \& Davis, J. H. (1991). Stewardship theory or agency theory: CEO governance and shareholder returns. Australian Journal of Management, 16(1), 49-64.

Duan, T., \& Hou, W. (2016). Returnee CEOs under weak institutions: Blessing or curse? Unpublished Working Paper. University of Edinburgh.

Earl, M. J., \& Scott, I. A. (1999). Opinion: What is a chief knowledge officer? Sloan Management Review, 40(2), 29-38.

Fan, J. P., Wong, T. J., \& Zhang, T. (2007). Politically connected CEOs, corporate governance, and Post-IPO performance of China's newly partially privatized firms. Journal of Financial Economics, 84(2), 330-357.

Finkelstein, S. (1992). Power in top management teams: Dimensions, measurement, and validation. Academy of Management Journal, 35(3), 505-538.

Finkelstein, S., \& D'aveni, R. A. (1994). CEO duality as a doubleedged sword: How boards of directors balance entrenchment avoidance and unity of command. Academy of Management Journal, 37(5), 1079-1108.

Geiger, M. A., \& North, D. S. (2006). Does hiring a new CFO change things? An investigation of changes in discretionary accruals. The Accounting Review, 81(4), 781-809.

Giannetti, M., Liao, G., \& Yu, X. (2013). The brain gain in corporate boards: Evidence from China. Journal of Finance, 70(4), 1629-1682.

Heflin, F., Kross, W. J., \& Suk, I. (2016). Asymmetric effects of regulation FD on management earnings forecasts. The Accounting Review, 91, 119-152.

Holley, D. M. (1998). Information disclosure in sales. Journal of Business Ethics, 17, 631-641.

Hopkins, J. J., Maydew, E. L., \& Venkatachalam, M. (2014). Corporate general counsel and financial reporting quality. Management Science, 61(1), 129-145.

Jensen, M., \& Meckling, W. (1976). Theory of the firm: Managerial behavior, agency costs and ownership structure. Journal of Financial Economics, 3, 305-360.

Jiang, J. X., Petroni, K. R., \& Wang, I. Y. (2010). CFOs and CEOs: Who have the most influence on earnings management? Journal of Financial Economics, 96(3), 513-526.

Kaplan, S. N., Klebanov, M. M., \& Sorensen, M. (2012). Which CEO characteristics and abilities matter? The Journal of Finance, 67(3), 973-1007.

Karamanou, I., \& Vafeas, N. (2005). The association between corporate boards, audit committees, and management earnings forecasts: An empirical analysis. Journal of Accounting Research, 43(3), 453-486.

Kasznik, R., \& Lev, B. (1995). To warn or not to warn: Management disclosures in the face of an earnings surprise. The Accounting Review, 70, 113-134.

Kross, W. J., Ro, B. T., \& Suk, I. (2011). Consistency in meeting or beating earnings expectations and management earnings forecasts. Journal of Accounting and Economics, 51, 37-57.

Kwak, B., Ro, B. T., \& Suk, I. (2012). The composition of top management with general counsel and voluntary information disclosure. Journal of Accounting and Economics, 54(1), $19-41$. 
Lee, D. (2015). Corporate social responsibility and management forecast accuracy. Journal of Business Ethics, 120(2), 353-367.

Lee, S., Matsunaga, S. R., \& Park, C. W. (2012). Management forecast accuracy and CEO turnover. The Accounting Review, 87(6), 2095-2122.

Li, H., Meng, L., Wang, Q., \& Zhou, L. A. (2008). Political connections, financing and firm performance: Evidence from Chinese private firms. Journal of Development Economics, 87(2), 283-299.

Matsumoto, D. A. (2002). Management's incentives to avoid negative earnings surprises. The Accounting Review, 77, 483-514.

McNulty, T., \& Stewart, A. (2015). Developing the governance space: A study of the role and potential of the company secretary in and around the Board of Directors. Organization Studies, 36(4), 513-535.

Nagar, V., Nanda, D., \& Wysocki, P. (2003). Discretionary disclosure and stock-based incentives. Journal of Accounting and Economics, 34(1), 283-309.

Nath, P., \& Mahajan, V. (2008). Chief marketing officers: A study of their presence in firms' top management teams. Journal of Marketing, 72(1), 65-81.

Nelson, J. (2005). Corporate governance practices, CEO characteristics and firm performance. Journal of Corporate Finance, 11(1), 197-228

Pfeffer, J., \& Salancik, G. R. (1978). The external control of organizations: A resource dependence approach. NY: Harper and Row Publishers.
Pownall, G., Wasley, C., \& Waymire, G. (1993). The stock price effects of alternative types of management earnings forecasts. The Accounting Review, 68, 896-912.

Rogers, J., \& Stocken, P. (2005). Credibility of management forecasts. The Accounting Review, 80, 1233-1260.

Ruppel, C. P., \& Harrington, S. J. (2000). The relationship of communication, ethical work climate, and trust to commitment and innovation. Journal of Business Ethics, 25, 313-328.

Skinner, D. J. (1994). Why firms voluntarily disclose bad news. Journal of Accounting Research, 32(1), 38-60.

Slater, D. J., \& Dixon-Fowler, H. R. (2009). CEO international assignment experience and corporate social performance. Journal of Business Ethics, 89(3), 473-489.

Trueman, B. (1986). Why do managers voluntarily release earnings forecasts? Journal of Accounting and Economics, 8(1), 53-71.

Windmeijer, F. (2005). A finite sample correction for the variance of linear efficient two-step GMM estimators. Journal of Econometrics, 126, 25-51.

$\mathrm{Xu}$, W. (2010). Do management earnings forecasts incorporate information in accruals? Journal of Accounting and Economics, 49(3), 227-246.

Yang, H. I. (2012). Capital market consequences of managers' voluntary disclosure styles. Journal of Accounting and Economics, 53(1), 167-184.

You, J., \& Du, G. (2012). Are political connections a blessing or a curse? Evidence from CEO turnover in China. Corporate Governance: An International Review, 20(2), 179-194. 